\title{
Genesis and dating of Late Pleistocene-Holocene soil sediment sequences from the Lüneburg Heath, Northern Germany
}

\author{
Brigitte Urban, Alexander Kunz, Ernst Gehrt
}

Abstract:

\begin{abstract}
The stratigraphy and settlement history of the loess-areas in Central Europe is well known for the glacial periods and the Holocene. In contrast there are no recent investigations in the sandy loess areas of the so called "Altmoränengebiet" in northern Germany on the age of the sediments, timing of soil formation and settlement history. In this study two soil profiles in the Lüneburg Heath are investigated. The soils have been studied by means of sedimentology, pedology and palynology. Dating was done by optically stimulated luminescence (OSL) and radiocarbon. The results give the first evidence from the Altmoränengebiet for human impact on soil development as early as the late Neolithic. In the soil profiles, periods of erosion and accumulation with enrichment in organic rich material are indicated.
\end{abstract}

[Genese und Datierung spätpleistozän-holozäner Paläobodensequenzen in der Lüneburger Heide, Norddeutschland]

Kurzfassung:

\begin{abstract}
Während in den Lössgebieten Mitteleuropas die Lössstratigraphie und die menschliche Besiedlung der Lössgebiete sowohl eiszeitlich wie auch im Holozän gut bekannt sind, liegen zu den Sandlössgebieten der Altmoränengebiete keine neueren Erkenntnisse zur zeitlichen Stellung der Sedimente oder zur Siedlungsgeschichte und zum Einfluss auf die Bodenentwicklung vor. In der Arbeit werden aus einem Sandlössgebiet in der Lüneburger Heide zwei Bodenprofile vorgestellt deren Gliederung einen Einblick in die Genese der vergangenen 10000 Jahre erlaubt. Die Profile wurden sedimentologisch, pedologisch und palynologisch untersucht und charakterisiert. Die Datierung der Profile erfolgte mittels optisch stimulierter Lumineszenz (OSL) und Radiokarbondatierung. Die Ergebnisse legen einen menschlichen Einfluss auf die Böden ab dem späten Neolithikum nahe. Darunter sind Erosions- und Akkumulationsprozesse und insbesondere eine Anreicherung mit organischem Material zu fassen. Erstmals können mit dieser Studie Datierungen von Sedimenten und Böden des Altmoränengebietes präsentiert werden.
\end{abstract}

Keywords: $\quad$ loess, palaeosols, luminescence dating, pollen analysis, palaeoenvironment, human impact

Addresses of authors: B. Urban, Institute of Ecology, Leuphana University Lüneburg, Herbert-Meyer-Str. 7, 29556 Suderburg, Germany. E-Mail: b.urban@uni.leuphana.de; A. Kunz, Section S3: Geochronology and Isotope Hydrology, Leibniz Institute for Applied Geophysics, Hannover, Germany (present address: Department of Geosciences, National Taiwan University, Taipeh, Taiwan (R.O.C.). E-Mail: a.kunz96@yahoo.com; E. Gehrt, State Authority for Mining, Energy and Geology of Lower Saxony (LBEG), Stilleweg 2, 30655 Hannover, Germany. E-Mail: e.gerth@lbeg.niedersachsen.de

\section{Introduction}

The present morphology of the Lüneburg Heath was mainly formed by the Saalian glaciation (Oxygen Isotope Stage $6-8)$, when the area was covered at least three times by ice. Weichselian glaciers (Oxygen Isotope Stage 2-5d) did not reach the area which was strongly influenced by periglacial processes, like erosion and solifluction. The landscape of the Lüneburg Heath is hence characterised by ground moraines, terminal moraines, outwash plains, glaciofluvial deposits and, in some limited areas, by loess deposits (Fig. 1) (HAGEDORn 1964, CASPERS et al. 1995).

From soil mapping it is known that 70 to $90 \mathrm{~cm}$ thick humic horizons in the soils of the sandy loess areas are common. These horizons occur in depressions but also on topographic highs. The formation of typical Plaggic Anthrosols (BLume \& LeINEWEBER 2004) is not known for the Lüneburg Heath. There are still questions about the age of these humic horizons and about their formation processes.

Our investigations concentrate on an area south of Lüneburg, near the village of Seedorf (Figs. 1 and 2) that is well-known for its highly fertile soils, which have developed on sandy loess ("Sandlöss") (Gehrt 2000). The sandy loess was deposited during the Upper Weichselian (Geological Map GK 25 2929) and is generally overlying Saalian and Lower and Middle Weichselian sediments. The prevailing soil types developed on sandy loess in the Lüneburg Heath were described by Roeschmann in Kuntze et al. (1995) and by GeHrT (2000). They range from Luvisols, stagnic Luvisols, Cambisols and Podzols to Fluvisols and Gleysols in the small brook valleys (Soil Map BK50 L2928, Bad Bevensen) (Fig. 3). Figure 4 shows the distribution of the characteristic deep humic horizons in the study area, which are classified as colluvium and generally overly the diagnostic B horizons. There is archaeological evidence of an Iron Age cultural stage of the Jastorf culture (SeedorfStufe, Schwantes 1952, Hässler 1991) though as well as of Neolithic settlements (Sprockhoff 1975, HeEge \& MAIER 1991, Geebers 1995, Richter 2002) in the area and of a number of archaeobotanical investigations from prehistoric sites. The few data available from peat bogs though provide background information on landscape development (Becker 1995, Kirleis 2003, Becker \& Urban 2006). This study of a Gleysol/Colluvisol developed in a brook valley and of a Colluvisol/stagnic Luvisol sequence developed on sandy loess at higher topographic elevation near the vil- 


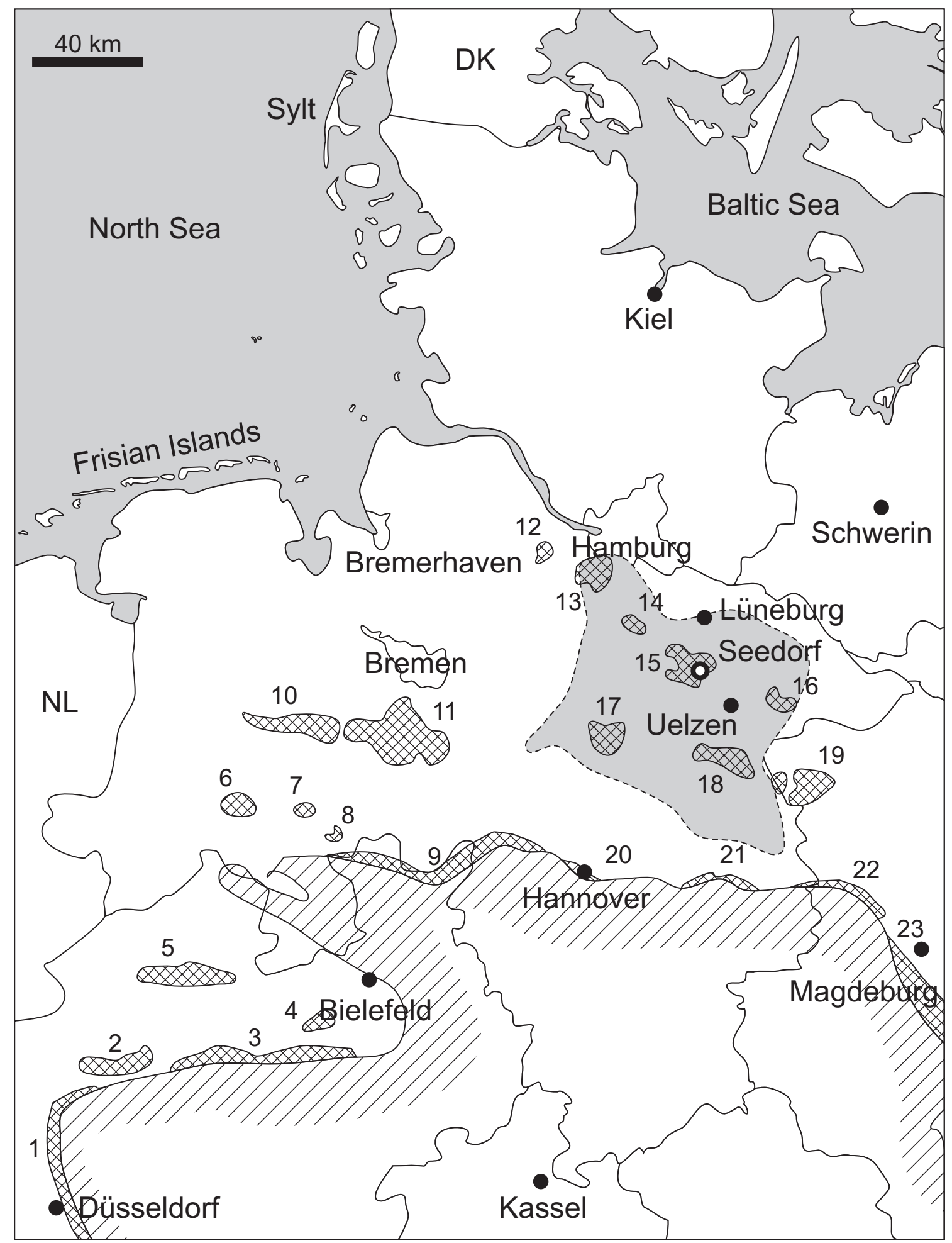

Fig. 1: Location of Seedorf, county of Uelzen, Lower Saxony and distribution of loess and sandy loess in northern Germany. Grey shaded area shows the location of the Luenburg Heath. Hatched area marks the northern most distribution of loess. Sandy loess areas are marked by cross-hatches. 1 = Lower Rhine Area; $2=$ Recklinghausen; 3, 4 = Soester Börde; $5=$ Münster; $6=$ Bersenbrück; $7=$ Damme; 8 = Wehden; 9 = Wunstorf, Rehurg; 10 = Goldenstedt 11 = Syke; 12 = Apensen; 13 = Harburg; $14=$ Garlsdorf; $15=$ Uelzen, Bevensen; $16=$ Clenze $; 17=$ Bergen, Jettebruch; $18=$ Wittingen $; 19=$ Klötze $; 20=$ Peine, Braunschweig; $21=$ Helmstedt $; 22=$ Haldensleben; 23 = Magdeburg.

Abb. 1: Lage von Seedorf (Landkreis Uelzen) in Niedersachsen und Verbreitung von Löss und Sandlöss in Nord-Deutschland. Die graue Fläche zeigt die Lage der Lüneburger Heide. Die schraffierte Fläche markiert die nördlichste Verbreitung von Löss in Deutschland. Sandlössgebiete sind durch Kreuzschraffur markiert. 1 = Niederrhein; 2 = Recklinghausen; 3, 4 = Soester Börde; $5=$ Münster; $6=$ Bersenbrück; 7 = Damme; $8=$ Wehden; $9=$ Wunstorf, Rehurg; $10=$ Goldenstedt $11=$ Syke; $12=$ Apensen; $13=$ Harburg; $14=$ Garlsdorf; $15=$ Uelzen, Bevensen $; 16=$ Clenze $; 17=$ Bergen, Jettebruch $; 18=$ Wittingen $; 19=$ Klötze $; 20=$ Peine, Braunschweig; $21=$ Helmstedt $;$ 22 = Haldensleben; 23 = Magdeburg 


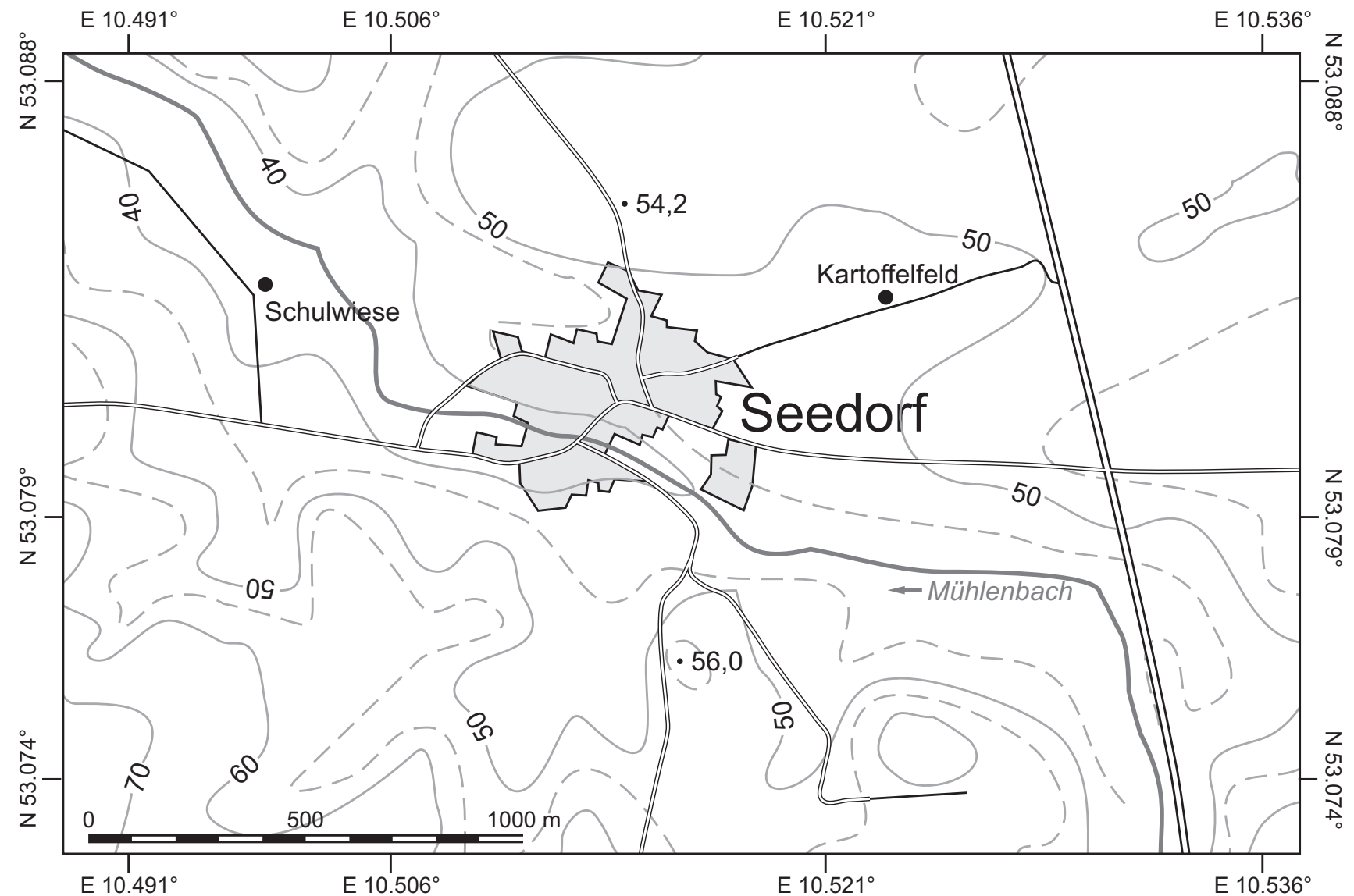

Fig. 2: Location of soil profiles Schulwiese and Kartoffelfeld near the village of Seedorf, county of Uelzen.

Abb. 2: Lage der untersuchten Profile Schulwiese und Kartoffelfeld in Seedorf (Landkreis Uelzen).

lage of Seedorf (Figs. 2 and 4) aims at dating and reconstructing (palaeo) environmental conditions of soil genesis and human impact on landscape evolution in the northernmost patchy sand loess region at the margin of the Western European contiguous loess belt.

\section{Materials and methods}

\subsection{Description of the soils of the studied sites}

Two sites have been selected for in-depth studies of their genetic development, which differ strongly in topography and hydrological conditions as well as in the type of land use. The prevailing soil types in the floodplains are Gleysols developed on alluvial deposits and Histosols that are mainly used as pasture, and stagnic Luvisols that are widespread at higher elevations and support arable agriculture (Fig. 3). The upper layers/horizons of the soils in both topographic positions are characterized by colluvial cover deposits.

The profiles of the two sites, Schulwiese and Kartoffelfeld, have been described in the field using the German soil mapping instructions (KA5 2005) (Tabs. 1 and 2), soil colour was determined by MuNSELL soil colour charts.

The investigated section Schulwiese (Figs. 2 and 4) $\left(53.08^{\circ} \mathrm{N}, 10.52^{\circ} \mathrm{E}, 38 \mathrm{~m}\right.$ a.s.l.) is located on a slip-off slope in a floodplain of a small watercourse close to the village of Seedorf in the western part of the Lüneburg Heath. The sequence consists of $1.75 \mathrm{~m}$ thick silty, clayey soil-sediment with fluvic and gleyic features. The uppermost $46 \mathrm{~cm}$ are made up of a colluvial cover layer. The entire sequence has a silty texture, which is moderately clayey to medium clayey from the middle part of the profile downwards (Tab. 1, Fig. 5). The profile is carbonate-free and the organic content ranges between weak to strong humic. The profile Schulwiese has been subdivided vertically using the international nomenclature (IUSS 2006) (Fig. 5). By applying the German soil classification system (KA5 2005), the vertical sequence was subdivided into Ap (0-14 cm) /M-Go $(14-46 \mathrm{~cm}) / \mathrm{aGo}(46-72 \mathrm{~cm})$ /fAa $+\mathrm{Gr}(72-104 \mathrm{~cm}) / \mathrm{aGr}(104-114 \mathrm{~cm}) / \mathrm{fAa}+\mathrm{aGr}(114-130$ $\mathrm{cm}) / \mathrm{aGr}(130-156 \mathrm{~cm}) / \mathrm{aGr}(156-175 \mathrm{~cm})$ (KuCz 2006). The Ap and the Bg1 horizon are developed in a loess colluvium (M-Go).

The profile Kartoffelfeld $\left(53.08^{\circ} \mathrm{N}, 10.52^{\circ} \mathrm{E}\right)$ is located northeast of the village of Seedorf at $47.80 \mathrm{~m}$ a.s.l on an elevated plateau (Figs. 2 and 4). The basal part of the $1.70 \mathrm{~m}$ thick profile is made up by Saalian glacial till underlain by glaciofluvial sands; the soil type developed on the silty sands is a stagnic Luvisol. From $133 \mathrm{~cm}$ upwards the stagnic Luvisol is overlain by a (sandy) loess colluvium showing weak cambic properties (Tab. 2). The organic content assessed ranges from weak to very weak humic. The profile Kartoffelfeld is vertically subdivided (IUSS 2006) into the horizons Ap-Bw1-Bw2-Bw3-2Btb/Bgb1-2Bwb1/Bgb1-3Bwb2/Bgb2/C (Fig. 6). By applying the German soil classification system (KA5 2005) the sequence of horizons can be described as Ap $(0-30 \mathrm{~cm}) / \mathrm{M}(30-54 \mathrm{~cm}) / \mathrm{M}(54-82 \mathrm{~cm}) / \mathrm{M}(82-110 \mathrm{~cm}) /$ Swd-Bt (110-133 cm) /Swd-Bv (133-138 cm) /Swd-Bv (138- 


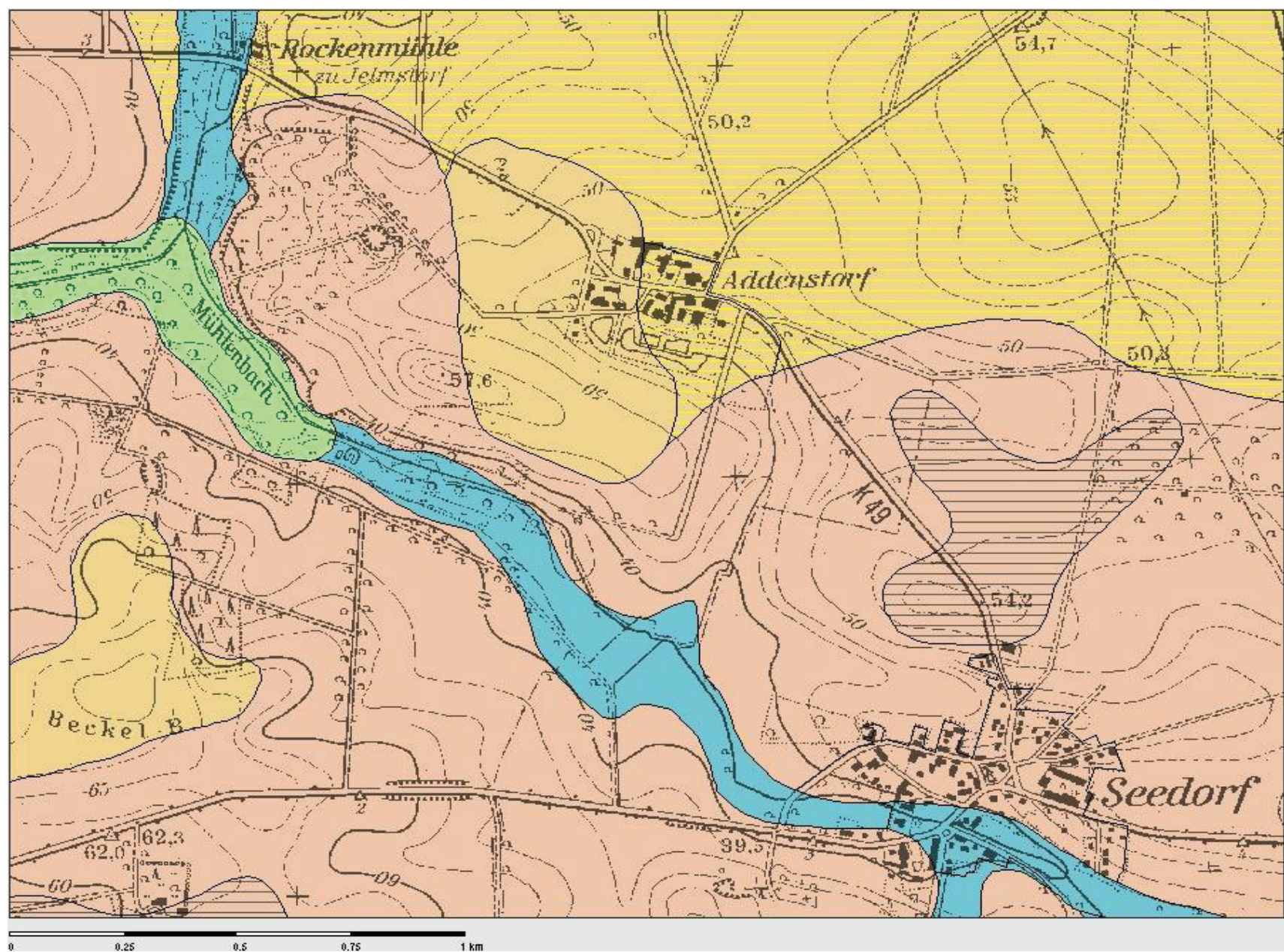

\section{Eutric Histosols}

Cambisols

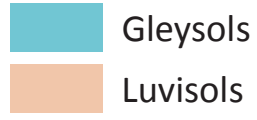

Luvisols
Stagnic Luvisols

Podzols, Cambisols

Fig. 3: Soil map of Uelzen (BK50 L2928, Bad Bevensen).

Abb. 3: Bodenkarte von Uelzen (BK50 L2928, Bad Bevensen).

$162 \mathrm{~cm}) / \mathrm{Cv}(162-170 \mathrm{~cm})$ (Kucz 2006). The Ap and Bw1, $\mathrm{Bw} 2, \mathrm{Bw} 3$ horizons developed within the loess colluvium (M $30-110 \mathrm{~cm})$.

\subsection{Sedimentological and pedological analysis}

The texture of the horizons was determined by the hydrometer method (VAN REEUwiJk 1992). For physico-chemical analysis, the same samples were taken and analyzed for their $\mathrm{pH}$ in a 1:2.5 0.01 $\mathrm{M} \mathrm{CaCl}_{2}$-suspension, for organic carbon $\left(\mathrm{C}_{\text {org }}\right)$ according to the Walkley-Black procedure (PAGE et al. 1982) and organic nitrogen using the Kjeldahl procedure. Major $(\mathrm{Al}, \mathrm{Fe}$, and $\mathrm{Mn}$ ) and trace $(\mathrm{S}, \mathrm{Cr}, \mathrm{Cu}, \mathrm{Pb}, \mathrm{Zn}, \mathrm{Co}, \mathrm{Ni}, \mathrm{Cd}$, $\mathrm{Sr}, \mathrm{Hg}, \mathrm{V})$ elements were determined using an X-ray fluorescence (XRF) spectrometer (SpectroXepos-Benchtop-Roentgenfluoreszenz-Spektrometer) equipped with a $\mathrm{Rh}$ tube (CHEN et al. 2001). Quality control of the analytical procedure was established using three internationally recognized standard reference materials (SRMs) viz., ISE, BCSS-1, and MESS-1. Based on these standards, the accuracy and precision of the analysis were within $1 \%$ for major elements and within $5 \%$ for trace elements. Oxalate $\mathrm{Fe}_{\mathrm{o}}$ and dithionite $\mathrm{Fe}_{\mathrm{d}}$ extractable iron (HoLMGREN 1967) were measured by inductively coupled plasma spectrometry (ICP). The soil organic matter (SOM) has been calculated as $\mathrm{C} \%{ }^{*} 1.72$. All analyses were carried out at Leuphana University Lüneburg, Germany.

\subsection{Age determination}

The depositional ages of the sediments were determined mainly by optically stimulated luminescence (OSL) with one sample for radiocarbon dating taken from the profile Schulwiese. The sampling positions are shown in Tabs. 7 and 8.

\subsubsection{Optically stimulated luminescence [OSL] dating}

OSL is one of the dosimetric dating methods and is an excellent tool for determining the depositional time of sediments. The method is based on the accumulation of electrons in defects of the crystal lattice induced by the natural radioactivity in the surrounding sediment. Due to the physical mechanism of the OSL method, reliable and precise results 


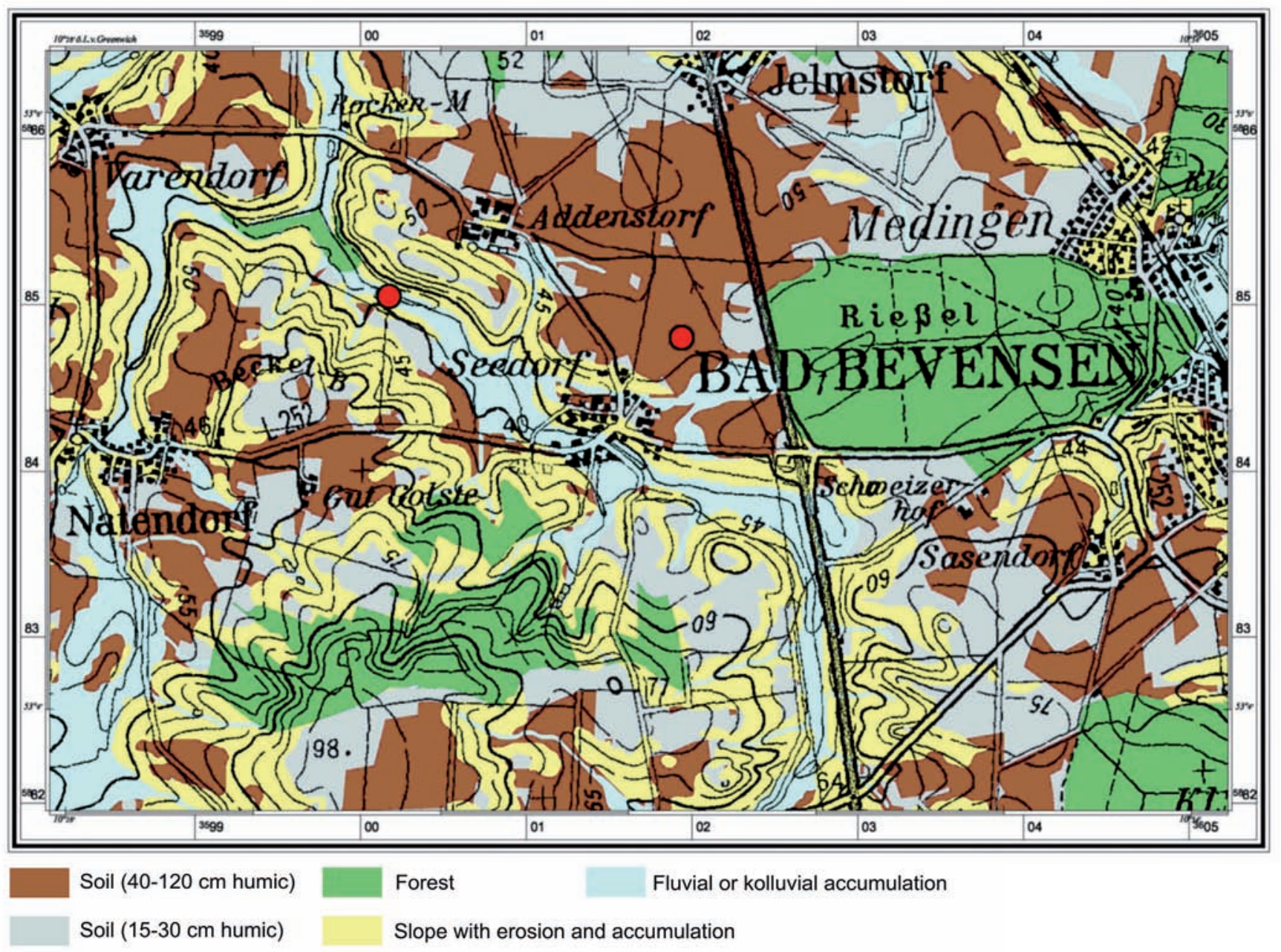

Fig. 4: Distribution of deep humic horizons, fluvial and colluvial layers and forest cover in the area of Seedorf/Bad Bevensen, county of Uelzen.

Abb. 4: Verbreitung von tief-humosen Böden, fluvialen und colluvialen Lagen und Waldbedeckung in der Umgebung von Seedorf/Bad Bevensen (Landkreis Uelzen).

for well-bleached aeolian sediments like loess or dunes can be determined. Therefore, OSL has been applied successfully to these deposits. Loess and loess like sediments have been investigated and dated with OSL in many studies (ROBERTS 2008). Loess research in Germany has a more than 175 year tradition with sections in the loess areas in the Rhineland (western Germany) and in southern Germany having been investigated in detail. The geochronological studies with thermoluminescence and OSL dating are summarized in Frechen et al. (2003). For loess and loess like sediments in northwest Germany geochronological studies are still missing. There are detailed sedimentological investigations done by Dewers (1932), Fiedler \& Altermann (1964) and LANG (1974, 1990). This study will provide the first OSL ages for the sandy loess area in northwest Germany.

Samples for OSL dating were collected in steel tubes hammered into vertical sediment exposures after cleaning the wall. The cylinders were sealed to protect the samples from light exposure. Preparation of fine grained material was done following the description from Frechen et al. (1996). For the OSL measurement, the grain size fraction between 4-11 $\mu \mathrm{m}$ was taken.

A Risø Reader TL/OSL-DA-15 was used for the measurement of the luminescence signal. The polymineral fine grain samples were stimulated with infrared LEDs with a wavelength of $875 \mathrm{~nm}$ and a maximum power of $135 \mathrm{~mW} \mathrm{~cm}{ }^{-2}$
The emitted light was detected with a bialkali EMI 9235QA photomultiplier tube. For the measurement of the feldspar emission a combination of a Schott BG 39 and a Corning 7-59 filter was used. Irradiation of the samples was done by an attached ${ }^{90} \mathrm{Sr} /{ }^{90} \mathrm{Y}$ beta source with a dose rate of 0.16 $\mathrm{Gy} \mathrm{s}^{-1}$. According to studies from MAUz \& LANG (2004) and MAUz et al. (2006), the dose rate has to be reduced for the calculation of the equivalent dose obtained with aluminium discs. Our experiments showed that the dose rate for our reader using fine grains on aluminium discs has to be $16 \%$ lower than for coarse grains (quartz) on stainless steel discs.

Feldspars suffer from an effect called anomalous fading. This is a non-thermal loss of charge from kinetically stable traps due to quantum mechanical tunnelling which results in age underestimation (SPOONER 1994, VISOCEKAS 2002, VisoceKas et al. 1994, WintLe 1973). A quantitative correction method for samples younger than $20 \mathrm{ka}$ was proposed by Huntley \& Lamothe (2001). This method for fading correction was applied to correct the ages for all samples in this study.

The natural luminescence signal is mainly the result of the natural radioactivity from uranium and thorium chains and ${ }^{40} \mathrm{~K}$ and a minor portion of some other radioisotopes and cosmic radiation. For the age calculation it is essential to know the annual dose rate of the surrounding sediment. In this study the dose rate was measured by gamma spectrome- 
Table 1: Field soil description of soil profile Schulwiese (Gleysol/Colluvisol).

Tabelle 1: Beschreibung der Bodenhorizonte des Profils Schulwiese ((Kolluvisol-)Gley).

\begin{tabular}{|l|l|l|l|l|}
\hline Horizon [KA5 2005] & Horizon [IUSS 2006] & Depth [cm] & Texture & Munsell Color \\
\hline $\mathrm{Ap}$ & $\mathrm{Ap}$ & $0-14$ & Silt & $2.5 Y 5 / 4$ \\
\hline $\mathrm{M}-\mathrm{Go}$ & $\mathrm{Bg} 1$ & $14-46$ & Silt & $2.5 Y 5 / 4$ \\
\hline $\mathrm{aGo}$ & Bg2 & $46-72$ & Moderate clayey Silt & $2.5 Y 4 / 4$ \\
\hline $\mathrm{fAa}+\mathrm{Gr}$ & 2Ahb/Crb & $72-104$ & Medium clayey Silt & $2.5 Y 4 / 3$ \\
\hline $\mathrm{aGr}$ & 2Crb & $104-114$ & Medium clayey Silt & $2.5 Y 4 / 3$ \\
\hline $\mathrm{fAa}+\mathrm{Gr}$ & $3 \mathrm{Ahb} / \mathrm{Crb}$ & $114-130$ & Moderate clayey Silt & $2.5 Y 2.5 / 1$ \\
\hline $\mathrm{aGr}$ & $3 \mathrm{Crb1}$ & $130-156$ & Moderate clayey Silt & $2.5 Y 4 / 2$ \\
\hline $\mathrm{aGr}$ & $3 \mathrm{Crb2}$ & $156-175$ & Moderate clayey Silt & Not determined \\
\hline
\end{tabular}

Table 2: Field soil description of soil profile Kartoffelfeld (Stagnic Luvisol/Colluvisol).

Tabelle 2: Beschreibung der Bodenhorizonte des Profils Kartoffelfeld (Kolluvisol, Pseudogley-Parabraunerde).

\begin{tabular}{|l|l|l|l|l|}
\hline Horizon [KA5 2005] & Horizon [IUSS 2006] & Depth [cm] & Texture \\
\hline Ap & Ap & $0-30$ & Silt & Silt \\
\hline M & Bw1 & $30-54$ & Moderate sandy Silt \\
\hline M & Bw2 & $54-82$ & Moderate sandy Silt & $2.5 Y 5 / 4$ \\
\hline M & Bw3 & $82-110$ & Strong silty Sand \\
\hline Swd-Bt & 2Btb/Bgb1 & $110-133$ YY5/6 & Medium silty Sand \\
\hline Swd-Bv & 2Bwb1/Bgb1 & $133-138$ & Weak silty Sand \\
\hline Swd-Bv & 3 Bwb2/Bgb2 & $138-162$ & Weak silty Sand \\
\hline Cv & C & $162-170$ & $2.5 Y 6 / 6$ \\
\hline
\end{tabular}

try with an HPGe (High-Purity Germanium) N-type coaxial detector in the laboratory. The results of the gamma spectrometry are shown in Table 3. For the dosimetry the infinite matrix approach is assumed (AITKEN 1998). This means for a volume having dimensions greater than the range of radiation, that the rate of energy absorption is equal to the rate of energy emission. The gamma spectrometry allows the monitoring for any radioactive disequilibrium. For all samples radioactive equilibrium could be observed. For potassium-rich feldspar the alpha contribution has to be corrected by a factor: the a-value (alpha efficiency). In this study an a-value of $0.08 \pm 0.01$ was used, as proposed by REEs-Jones (1995) for polymineral fine grain samples. The contribution of the cosmic radiation, which depends on latitude, longitude, altitude and thickness of the sediment cover, was calculated using the approach of Prescott \& Hutton (1994) and Prescott of STEPHAN (1982). The values for the cosmic radiation are shown in Table 3.

The intensity of the natural radioactivity in the sediment is attenuated by the water in the sediment. Therefore the annual dose rate has to be corrected. For the samples from the profile Schulwiese the water content was measured in the lab from additional samples taken during the OSL sampling. The water content for the upper samples is around $12 \%$. This is a typical value for European loess (PÉcSI 1990). The samples at lower positions are within the influence of the ground water. Here the water content is between 19 and $25 \%$. To take seasonal fluctuations of the water content into account, the error was set quite large. For the upper samples it is $5 \%$ and for the lower samples $10 \%$ (Tab. 3). For the samples from the profile Kartoffelfeld (Tab. 3) no water content was measured because there was not enough sampling material collected to measure the water content in the lab. In this case the water content had to be estimated using the values from the higher part of the nearby profile Schulwiese.

The OSL-ages are calculated by dividing the equivalent dose $\left(D_{e}\right)$ by the dose rate of the sediment including the contribution of the cosmic rays and the attenuation by the water content. The obtained ages were fading corrected with the g-value by the method described in HuntLey \& LAMOTHE (2001). The equivalent doses are calculated using the weighted mean. The results of the age calculation are shown in Tab. 4. The distribution of the equivalent doses was checked using the Kolmogorov-Smirnov-Test (K-S-test) which shows if there is a normal distribution or not. For a normal distribution the obtained K-S-value from this test should be lower than the critical test value. The results of the K-S-test are shown in Tab. 4. All samples show a normal distribution. Based on these results an incomplete bleaching of the samples is unlikely. 


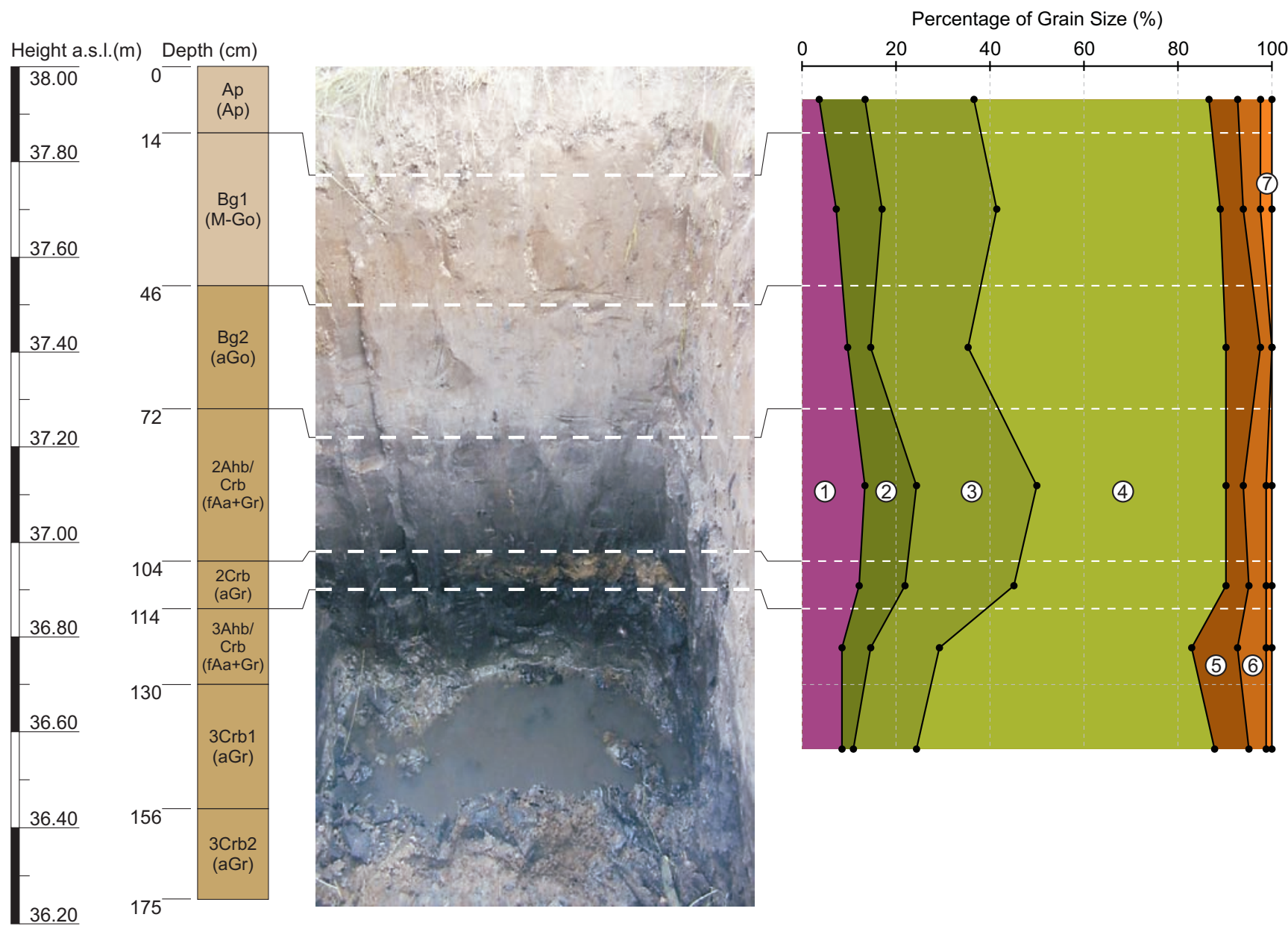

Fig. 5: Profile Schulwiese (Gleysol/Colluvisol) and grain size distribution. Soil description based on IUSS (2006) and in brackets on KA 5 (2005). $1=$ clay $(<0.002 \mathrm{~mm}), 2=$ fine grained silt $(0.002-0.006 \mathrm{~mm}), 3=$ middle grained silt $(0.006-0.02 \mathrm{~mm}), 4=$ coarse grained silt $(0.02-0.063 \mathrm{~mm}), 5=$ fine grained sand (0.063-0.2 $\mathrm{mm}), 6=$ middle grained sand $(0.2-0.63 \mathrm{~mm}), 7$ = coarse grained sand $(0.63-2 \mathrm{~mm})$.

Abb. 5: Profil Schulwiese ((Kolluvisol-)Gley) und Korngrössenverteilung. Bodenbeschreibung nach IUS (2006) und in Klammern nach KA 5 (2005). $1=$ Ton $(<0,002 \mathrm{~mm}), 2=$ Feinschluff $(0,002-0,006 \mathrm{~mm}), 3=$ Mittelschluff $(0,006-0,02 \mathrm{~mm}), 4=$ Grobschluff $(0,02-0,063 \mathrm{~mm}), 5=$ Feinsand $(0,063-0,2 \mathrm{~mm}), 6=$ Mittelsand $(0,2-0,63 \mathrm{~mm}), 7=$ Grobsand $(0,63-2 \mathrm{~mm})$.

\subsubsection{OSL measurements and experimental details}

Before starting the OSL measurements with a single aliquot regenerative dose (SAR) protocol, several tests were performed to check the suitability of the material for dating. The SAR protocol based on Murray \& WinTLE (2000) was used in this study. The protocol was modified by inserting a hot-bleach step and the cutheat temperature was chosen equivalent to the preheat temperature (WALLINGA et al. 2007). Preheat tests, dose recovery tests and fading tests were performed. The tests were made for the top-most samples and the bottom-most samples in the profiles. Samples SEE 1-A and SEE 1-F from profile Schulwiese and samples SEE 2-A and SEE 2-C from profile Kartoffelfeld were used for preheat tests. Samples SEE 1-C and SEE 2-A were used for a dose recovery test. The fading tests were done for all samples using fresh aliquots.

The results of the preheat plateau test are shown in Fig. 7. For the samples from profile Schulwiese, the $\mathrm{D}_{\mathrm{e}}$ show a plateau in the temperature range of $160^{\circ} \mathrm{C}$ to $240^{\circ} \mathrm{C}$ (SEE 1-A) and $180^{\circ} \mathrm{C}$ to $240^{\circ} \mathrm{C}$ (SEE 1-F). For higher preheat temperatures the $\mathrm{D}_{\mathrm{e}}$ are increasing significantly. The recycling ratios are in the range of acceptance of $1.0 \pm 0.1$ for preheat temperatures up to $240^{\circ} \mathrm{C}$. For higher preheat temperatures the recycling ratios are decreasing. The recuperation is increasing for preheat temperatures higher than $240^{\circ} \mathrm{C}$. Based on these results a preheat temperature of $200^{\circ} \mathrm{C}$ for all the samples from profile Schulwiese was used.

The behaviour for the samples from profile Kartoffelfeld differs. There is no clear preheat plateau visible for the samples SEE 2-A and SEE 2-C. The $\mathrm{D}_{\mathrm{e}}$ are slightly increasing with increasing preheat temperature. The recycling ratios are decreasing and scattering for preheat temperatures higher than $220^{\circ} \mathrm{C}$. The recuperation is increasing exponentially for preheat temperatures higher than $200^{\circ} \mathrm{C}$. Based on the behaviour of the recycling ratios and recuperation, a preheat temperature of $180^{\circ} \mathrm{C}$ was used for all samples from the profile Kartoffelfeld.

After determination of the appropriate preheat tempe-rature, dose-recovery tests based on the protocol described by MurRAY \& Wintle (2003) were carried out. This test determines whether an artificially applied dose can be recovered by the SAR protocol. For the profile Schulwiese 15 aliquots from sample SEE 1-C and 10 aliquots from sample SEE 2-A (profile Kartoffelfeld) were bleached in a Dr. Hönle SOL 2 solar simulator for 2 hours. The bleached samples are irradiated in the Risø Reader with a fixed beta-dose which is close to the expected equivalent dose. This dose was measured us- 
Table 3: Results of the gamma spectrometry, cosmic dose and water content for the samples from section Schulwiese (SEE 1) and section Kartoffelfeld (SEE 2). Depth is below surface. The dose rate is the sum of the dose rates from the alpha, beta, gamma and cosmic radiation. For the calculation of the total dose rate the conversion factors published by ADAMIEC \& AITKEN (1998) were used. An a-value of 0.08 \pm 0.01 (REES-JONES 1995) for the alpha-efficiency was used for all samples. A systematic error of $8 \%$ is included for the calculation of the dose rate including uncertainties from beta-attenuation, conversion factors, calibration of the gamma detector and effects of past disequilibrium. An error of $10 \%$ is estimated for the cosmic dose.

Tabelle 3: Ergebnisse der Gammaspektrometrie, kosmischen Strahlung und Wassergehalt für die Proben aus dem Profil Schulwiese (SEE 1) und Profil Kartoffelfeld (SEE 2). Tiefe ist unter Geländeoberkante. Die Dosisleistung des Sediments ist die Summe aus den Dosisleistungen der alpha-, beta-, gamma- und kosmischen Strahlung. Für die Berechnung der gesamten Dosisleistung wurden die Umrechnungsfaktoren von ADAMIEC \& AITKEN (1998) verwendet. Zur Berechnung der alpha-Effizienz wurde der a-Wert von 0,08 \pm 0,01 für alle Proben verwendet (REES-JoNES 1995). Ein systematischer Fehler von 8\% wurde bei der Berechnung der Dosisleistung einbezogen. Dieser Fehler beinhaltet Unsicherheiten durch die beta-Abschwächung, der Umrechnungsfaktoren, der Kalibrierung des Gammaspektrometers und Effekte durch frühere radioaktive Ungleichgewichte. Für die kosmische Strahlung wurde ein Fehler von 10\% angenommen.

\begin{tabular}{|c|c|c|c|c|c|c|c|}
\hline Sample & depth [m] & $\begin{array}{c}\text { water } \\
\text { content [\%] }\end{array}$ & $K[\%]$ & U [ppm] & Th [ppm] & $\begin{array}{l}\text { cosmic dose } \\
{\left[\mathrm{mGy} \mathrm{a}^{-1}\right]}\end{array}$ & $\begin{array}{l}\text { dose rate } \\
{\left[\mathrm{mGy}^{-1}\right]}\end{array}$ \\
\hline SEE 1-A & 0.30 & $12 \pm 5$ & $1.48 \pm 0.07$ & $2.02 \pm 0.10$ & $6.45 \pm 0.32$ & $0.20 \pm 0.02$ & $2.78 \pm 0.17$ \\
\hline SEE 1-B & 0.45 & $11 \pm 5$ & $1.56 \pm 0.08$ & $2.34 \pm 0.12$ & $7.09 \pm 0.35$ & $0.20 \pm 0.02$ & $3.04 \pm 0.17$ \\
\hline SEE 1-C & 0.60 & $13 \pm 5$ & $1.63 \pm 0.08$ & $2.27 \pm 0.11$ & $7.54 \pm 0.38$ & $0.19 \pm 0.02$ & $3.05 \pm 0.17$ \\
\hline SEE 1-D & 0.85 & $19 \pm 10$ & $1.55 \pm 0.08$ & $2.50 \pm 0.13$ & $8.06 \pm 0.40$ & $0.18 \pm 0.02$ & $2.92 \pm 0.20$ \\
\hline SEE 1-E & 0.97 & $25 \pm 10$ & $1.31 \pm 0.07$ & $2.51 \pm 0.13$ & $7.13 \pm 0.36$ & $0.18 \pm 0.02$ & $2.49 \pm 0.18$ \\
\hline SEE 1-F & 1.15 & $17 \pm 10$ & $1.41 \pm 0.07$ & $2.25 \pm 0.11$ & $6.94 \pm 0.35$ & $0.17 \pm 0.02$ & $2.67 \pm 0.20$ \\
\hline SEE २-A & 0.80 & $12 \pm 5$ & $1.70 \pm 0.09$ & $2.28 \pm 0.11$ & $6.90 \pm 0.35$ & $0.18 \pm 0.02$ & $3.08 \pm 0.17$ \\
\hline SEE २-B & 0.82 & $12 \pm 5$ & $1.71 \pm 0.09$ & $2.21 \pm 0.11$ & $6.79 \pm 0.34$ & $0.18 \pm 0.02$ & $3.06 \pm 0.17$ \\
\hline SEE २-C & 1.38 & $12 \pm 5$ & $1.20 \pm 0.06$ & $2.45 \pm 0.12$ & $8.91 \pm 0.45$ & $0.17 \pm 0.02$ & $2.86 \pm 0.17$ \\
\hline
\end{tabular}

ing the SAR protocol applied for the samples. The ratio of applied dose to recovered dose for sample SEE $1-C$ is $0.94 \pm 0.03$ and for sample SEE 2-A is $1.03 \pm 0.01$. Based on the results of the performance tests a SAR protocol (Tab. 5) was developed and the $\mathrm{D}_{\mathrm{e}}$ values of the samples are measured with this protocol. The IR-stimulation time for the samples from profile Schulwiese are reduced from $300 \mathrm{~s}$ to $100 \mathrm{~s}$ to save measuring time. The IRSL-signal is reduced after $50 \mathrm{~s}$ to backgroundlevel. Longer IR-stimulation time gives no better behaviour concerning fully bleaching and recuperation.

\subsection{Palynological investigations}

For palynological, including charcoal particle, analysis, about $10 \mathrm{~g}$ sampled at intervals of $2-5 \mathrm{~cm}$ of the OSL dated layers were treated by standard palynological methods. The procedures included dispersion with $10 \% \mathrm{NaOH}$, carbonate removal by $10 \% \mathrm{HCl}$, flotation to separate organics from the inorganic matrix using sodium metatungstate $\left(3 \mathrm{NaWO}_{4}\right.$ - $\left.9 \mathrm{WO}_{3} \cdot \mathrm{H}_{2} \mathrm{O}\right)$ and acetolysis to dissolve cellulose and to darken the palynomorphs for ease of recognition (FAEGRI $d$ IVERSEN 1989, Moore et al. 1991). Prepared residues were embedded in glycerine over which coverslips of 24 x $32 \mathrm{~mm}$ were sealed with Entellan ${ }^{\circledR}$ and samples subsequently counted mostly at x400 magnification. Three slides of 24 x $32 \mathrm{~mm}$ per sample were analyzed for pollen and non-pollen palynomorphs except for micro charcoal, which was counted in 1 slide and then calculated for 3 slides as well. For detailed morphological studies a x100 oil immersion lens was used. Pollen and spores were identified from the atlases of Moore et al. (1991), Beug (2004), FAegri \& Iversen (1989) and a reference collection of the Laboratory of the Division of Soil Science and Biology at Leuphana University of Lüneburg.
The guide and reference literature of van GeEL $(1978,2001)$ was used to identify fungal remains and other non-pollen palynomorphs. The pollen sum $(100 \%)$ is based on terrestrial pollen exclusive of Cyperaceae and Ericaceae as well as fern and moss spores. Pollen calculation and diagram construction were performed with the software package TILIA, TILIA GRAPH and TILIA VIEW (GRIMM 1990).

\section{Results}

\subsection{Sediment and soil properties}

\subsubsection{Profile Schulwiese}

The Ap and Bg1 horizons (colluvium) of the Gleysol/Colluvisol Schulwiese (Tab. 1, Figs. 5 and 8) are characterized by pure silt, the underlying buried Ahb and Crb horizons are composed of moderate clayey silt, and the $2 \mathrm{Ahb} / \mathrm{Crb}$ horizon has the highest clay content. The $\mathrm{pH}\left[\mathrm{CaCl}_{2}\right]$ of the entire profile ranges from 5.6 to 5.8 except for the $\mathrm{Bg} 2$ horizon, which has a pH of slightly above 6. Organic carbon and Soil Organic Matter (SOM) respectively reach highest values in the buried A horizons $2 \mathrm{Ahb} / \mathrm{Crb}(2.66 \% \mathrm{C})$ and $3 \mathrm{Ahb} / \mathrm{Crb}$ $(2.25 \% \mathrm{C})$ and in the Ap $(2.03 \% \mathrm{C})$ and Bg1 $(1.87 \% \mathrm{C})$ horizons which developed on the colluvium. The $2 \mathrm{Crb}$ horizon has still a carbon content of $1.15 \%$ whereas the $\mathrm{Bg} 2(0.5 \%)$ and the $3 \operatorname{Crb} 1(0.44 \%)$ horizons are low in carbon. Similar results were found for organic nitrogen with highest amounts in the buried A horizons and in the horizons developed within the colluvium (Fig. 8). Total $\left(\mathrm{Fe}_{\mathrm{t}}\right)$ as well as free iron $\left(\mathrm{Fe}_{\mathrm{d}}\right)$ have highest values in the uppermost colluvial horizons Ap and Bg1 (Fig. 9 and 10) pointing to supply with fresh loesssoil borne material. Among the trace and major elements the 
Table 4: Results of the OSL measurements, age calculation and statistical parameters for the samples from section Schulwiese (SEE 1) and the section Kartoffelfeld (SEE 2). The grain size for all samples is 4-11 $\mu \mathrm{m}$. Equivalent doses are calculated using weighted mean including an error of $3 \%$ for the calibration of the beta source in the OSL reader. Fading corrected ages are calculated using the approach from HUNTLEY \& LAMOTHE (2001). Number of aliquots shows the amount of aliquots used for the age calculation. The K-S-value shows the results of the Kolmogorov-Smirnoff-Test which tests for a normal distribution. Distributions of equivalent doses with K-S-values lower than the critical K-S-value are regarded as normal distributions.

Tabelle 4: Ergebnisse der OSL-Messung, der Altersberechnung und statistische Parameter für die Proben aus dem Profil Schulwiese (SEE 1) und Kartoffelfeld (SEE 2). Alle Proben sind polymineralische Feinkornproben mit einer Korngrösse zwischen $4 \mu$ m und $11 \mu$ m. Die Äquivalenzdosen wurden über das gewichtete Mittel berechnet. Die Fehlerberechnung beinhaltet einen Fehler für die Kalibrierung der beta-Quelle im OSL-Reader von 3\%, Die Fadingkorrektur wurde nach der Methode von HunTLEY \& LAMOTHE (2001) durchgeführt. Anzahl der Aliquots zeigt die Zahl der für die Altersberechnung verwendeten Aliquots an. Mit Hilfe des Kolmogorov-Smirnoff-Test wurden die Verteilungen der Äquivalenzdosen auf Normalverteilung getestet. Verteilungen mit einem K-S-Wert niedriger als der kritische K-S-Wert wurden als Normalverteilung angesehen.

\begin{tabular}{|c|c|c|c|c|c|c|c|}
\hline Sample & $\begin{array}{l}\text { equivalent } \\
\text { dose }[\mathrm{Gy}]\end{array}$ & $\begin{array}{c}\text { g-value } \\
\text { [\% per decade] }\end{array}$ & $\begin{array}{c}\text { fading uncorrected } \\
\text { age [ka] }\end{array}$ & $\begin{array}{l}\text { fading corrected age } \\
\text { [ka] }\end{array}$ & $\begin{array}{l}\text { number of } \\
\text { aliquots }\end{array}$ & K-S-value & $\begin{array}{c}\text { critical K-S- } \\
\text { value }\end{array}$ \\
\hline SEE 1-A & $2.18 \pm 0.02$ & $5.4 \pm 0.3$ & $0.79 \pm 0.05$ & $1.2 \pm 0.1$ & 18 & 0.142 & 0.309 \\
\hline SEE 1-B & $2.10 \pm 0.03$ & $5.1 \pm 0.2$ & $0.69 \pm 0.04$ & $1.0 \pm 0.1$ & 18 & 0.115 & 0.309 \\
\hline SEE 1-C & $5.47 \pm 0.06$ & $4.4 \pm 0.2$ & $1.8 \pm 0.1$ & $2.5 \pm 0.1$ & 19 & 0.161 & 0.301 \\
\hline SEE 1-D & $5.50 \pm 0.06$ & $4.5 \pm 0.2$ & $1.9 \pm 0.1$ & $2.6 \pm 0.2$ & 20 & 0.138 & 0.294 \\
\hline SEE 1-E & $7.28 \pm 0.08$ & $3.9 \pm 0.3$ & $2.9 \pm 0.2$ & $3.9 \pm 0.3$ & 20 & 0.089 & 0.294 \\
\hline SEE 1-F & $19.16 \pm 0.28$ & $2.9 \pm 0.3$ & $7.2 \pm 0.6$ & $9.0 \pm 0.7$ & 20 & 0.106 & 0.294 \\
\hline SEE २-A & $10.78 \pm 0.10$ & $3.5 \pm 0.3$ & $3.5 \pm 0.2$ & $4.6 \pm 0.3$ & 20 & 0.101 & 0.294 \\
\hline SEE 2-B & $6.04 \pm 0.06$ & $3.8 \pm 0.2$ & $2.0 \pm 0.1$ & $2.6 \pm 0.1$ & 20 & 0.171 & 0.294 \\
\hline SEE 2-C & $138.99 \pm 2.00$ & $3.5 \pm 0.3$ & $48.5 \pm 2.9$ & $66.9 \pm 4.5$ & 17 & 0.087 & 0.318 \\
\hline
\end{tabular}

Table 5: Single aliquot regenerative (SAR) protocol used for the measurement of the samples from sections Schulwiese and Kartoffelfeld.

Tabelle 5: Für die Messung der Proben aus den Profilen Schulwiese und Kartoffelfeld benutztes Single Aliquot Regenerative (SAR) Protokoll.

\begin{tabular}{|l|l|l|l|l|}
\hline Step & Treatment & Schulwiese & Kartoffelfeld & Observed \\
\hline 1 & give regenerative dose $\mathrm{D}_{\mathrm{i}}$ & $1.6-48 \mathrm{~Gy}$ & $9.6-160 \mathrm{~Gy}$ & \\
\hline 2 & preheat $\left[5^{\circ} \mathrm{C} / \mathrm{s}\right.$ heating rate] & $200^{\circ} \mathrm{C}$ for $10 \mathrm{~s}$ & $180^{\circ} \mathrm{C}$ for $10 \mathrm{~s}$ & \\
\hline 3 & IRSL & $100 \mathrm{~s} @ 50^{\circ} \mathrm{C}$ & $300 \mathrm{~s} @ 50^{\circ} \mathrm{C}$ & $\mathrm{L}_{\mathrm{i}}$ \\
\hline 4 & give test dose $\mathrm{D}_{\mathrm{t}}$ & $0.8 \mathrm{~Gy}$ & $1.6 \mathrm{~Gy}$ & \\
\hline 5 & cutheat $\left[5^{\circ} \mathrm{C} / \mathrm{s}\right.$ heating rate] & $200^{\circ} \mathrm{C}$ for $10 \mathrm{~s}$ & $180^{\circ} \mathrm{C}$ for $10 \mathrm{~s}$ & \\
\hline 6 & IRSL & $100 \mathrm{~s} @ 50^{\circ} \mathrm{C}$ & $300 \mathrm{~s} @ 50^{\circ} \mathrm{C}$ & $\mathrm{T}_{\mathrm{i}}$ \\
\hline 7 & IRSL [hotbleach] & $100 \mathrm{~s} @ 290^{\circ} \mathrm{C}$ & $100 \mathrm{~s} @ 290^{\circ} \mathrm{C}$ & \\
\hline
\end{tabular}

For the natural sample $i=0$ and $D_{0}=0$. The whole sequence is repeated for several regenerative doses, including a zero dose and a repeat dose. Regenerative doses $D_{i}$ depending on the expected age of the sample. Doses are chosen in that way, that they bracket the natural dose. In this table the range of all given doses for all samples is given. The ratio between $L_{i} / T_{i}$ is used for the calculation of the equivalent dose. The IRSL-signal from step 7 (hotbleach) is not used.

amounts of phosphorous, manganese as well as of chlorine are increasing in the Ap and Bg1 horizon (Fig. 10), whereas calcium and sulfur are predominant in fossil horizons $2 \mathrm{Ahb} / \mathrm{Crb}$ and $3 \mathrm{Ahb} / \mathrm{Crb}$. The sulfur enrichment might be explained as a result of anaerobic processes under (ground) water saturated conditions, which is as well supported by the high amounts of still preserved SOM.

\subsubsection{Profile Kartoffelfeld}

The Ap, Bw1, Bw2 and Bw3 horizons, which are developed on the loess-soil colluvium, are characterized by a silty $(0-54 \mathrm{~cm})$ to moderate sandy silty texture $(54-110 \mathrm{~cm})$ (Fig. 6, Tab. 2). The texture of 2Btb/Bgb1 $(110-133 \mathrm{~cm})$ is a strong silty sand and that of $2 \mathrm{Bwb} 1 / \mathrm{Bgb} 1(133-138 \mathrm{~cm})$ a medium silty sand while the $3 \mathrm{Bwb} 2 / \mathrm{Bgb} 2$ and $\mathrm{C}$ horizons are of a weak silty sand texture. 2Btb/Bgb1 $(110-133 \mathrm{~cm})$ and 2Bwb1/Bgb1 (133-138 cm) horizons developed on Weichselian periglacial silty sand, whereas the basal 3Bwb2/Bgb2 and C horizons formed on Saalian (Drenthe Stadium) sandy till. The uppermost four horizons show a steady increase of organic Carbon, total Nitrogen as well as of $\mathrm{pH}\left[\mathrm{CaCl}_{3}\right]$ (Fig. 11) from about $100 \mathrm{~cm}$ to the top of the profile. Total $\left(\mathrm{Fe}_{\mathrm{t}}\right)$ as well as free Iron $\left(\mathrm{Fe}_{\mathrm{d}}\right)$ in particular $\mathrm{Fe}_{\mathrm{o}}$-oxides have highest values in the uppermost colluvial horizons (Fig. 12) pointing to recent rejuvenation of the sequence with loesssoil borne parent material. The $\mathrm{Fe}_{\mathrm{o}} / \mathrm{Fe}_{\mathrm{t}}$ ratio of the underlying buried stagnic luvic and $\mathrm{C}$ horizons is very low reflecting old pedogenic weathering processes. A major erosive hiatus between the basic horizons and the colluvial cover pediment is assumed as a buried Ahb horizon is missing in the sequence of profile Kartoffelfeld. 


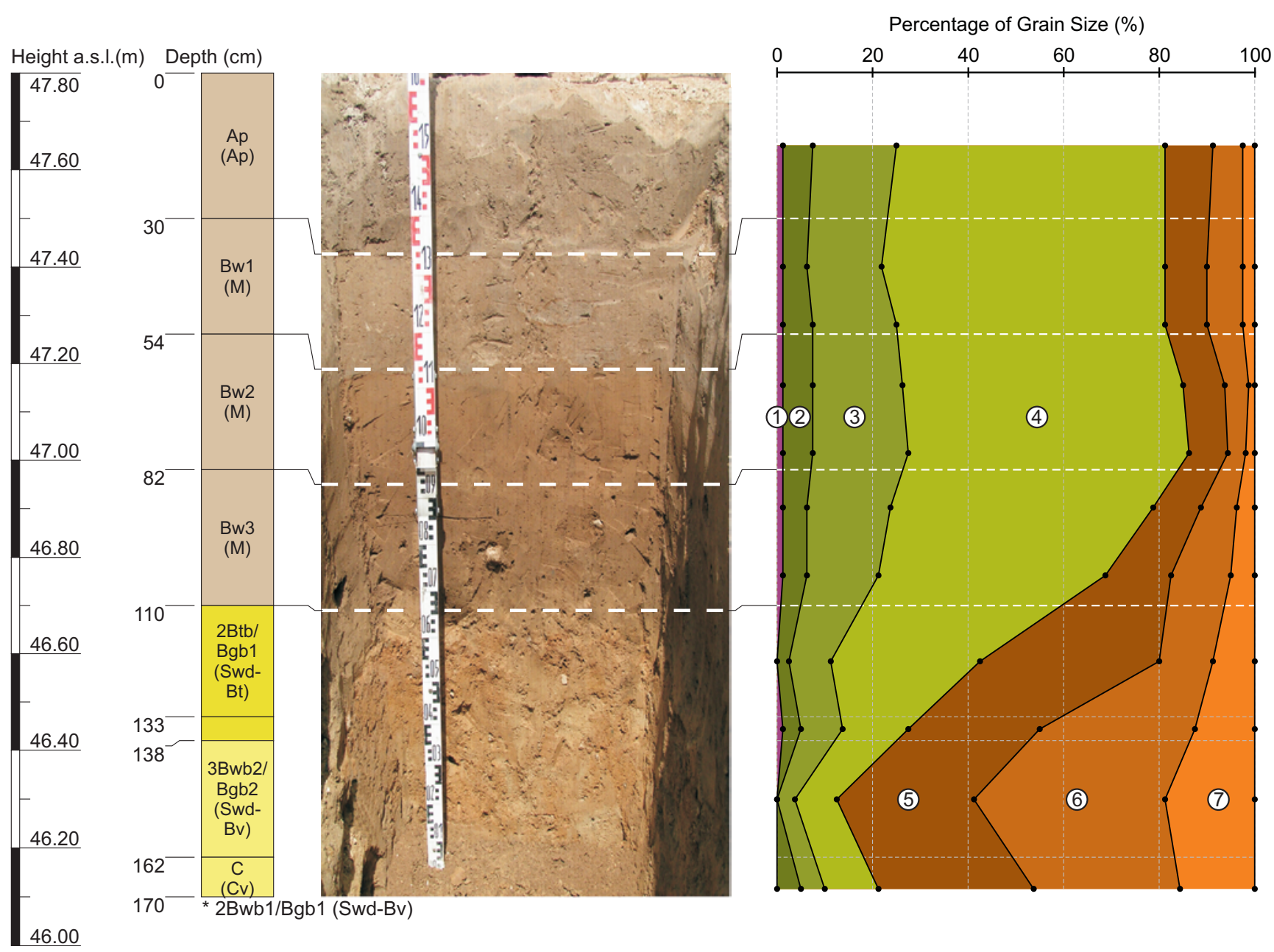

Fig. 6: Profile Kartoffelfeld (Colluvisol/Stagnic Luvisol) (Seedorf, Lower Saxony) and grain size distribution. Soil description based on IUSS (2006) and in brackets on KA 5 (2005). 1 = clay $(<0.002 \mathrm{~mm}), 2=$ fine grained silt $(0.002-0.006 \mathrm{~mm}), 3=$ middle grained silt $(0.006-0.02 \mathrm{~mm}), 4=$ coarse grained silt $(0.02-0.063 \mathrm{~mm}), 5$ = fine grained sand $(0.063-0.2 \mathrm{~mm}), 6=$ middle grained sand $(0.2-0.63 \mathrm{~mm}), 7=$ coarse grained sand $(0.63-2 \mathrm{~mm})$.

Abb. 6: Profil Kartoffelfeld (Kolluvisol, Pseudogley-Parabraunerde) und Korngrössenverteilung. Bodenbeschreibung nach IUS (2006) und in Klammern nach KA 5 (2005). 1 = Ton (<0,002 mm), $2=$ Feinschluff $(0,002-0,006 \mathrm{~mm}), 3=$ Mittelschluff $(0,006-0,02 \mathrm{~mm}), 4=$ Grobschluff $(0,02-0,063 \mathrm{~mm}), 5=$ Feinsand $(0,063-0,2 \mathrm{~mm}), 6=$ Mittelsand $(0,2-0,63 \mathrm{~mm}), 7$ = Grobsand $(0,63-2 \mathrm{~mm})$.

\subsection{OSL dating}

The results of the dosimetry, the OSL measurements and the age calculation for profiles Schulwiese and Kartoffelfeld are summarized in Tables 3 and 4. The equivalent doses and calculated ages, fading uncorrected and fading corrected ones, show an increase of $D_{e}$ and of age with depth. Sample SEE 1-B has a slightly lower $D_{e}$ and lower age than the sample from above. The 1-sigma standard deviation makes an equal deposition age likely for SEE 1-A and SEE 1-B. Based on the geochronology, four periods of increased accumulation of sediment can be identified in the profile Schulwiese. The first one took place $9.0 \pm 0.7 \mathrm{ka}$ while a second period is indicated at $3.9 \pm 0.3 \mathrm{ka}$. Samples SEE 1-C and SEE 1-D show a third period of deposition at around $2.5 \mathrm{ka}$ and the fourth period of deposition is shown by samples SEE 1-A and SEE 1-B at around $1.0 \mathrm{ka}$ before present.

In profile Kartoffelfeld there is an increase of $\mathrm{D}_{\mathrm{e}}$ and age with depth. The sample SEE 2-A was taken from a parallel profile a few meters from the main profile. It could be expected, that the ages of SEE 2-A and SEE 2-B should be nearly the same. The difference can be explained by the palaeo-topographic situation at this site which was not evident during sampling.
Due to the colluvial deposition of the sediment, incomplete bleaching of the samples could be expected. In the case of incomplete bleaching the distributions of the equivalent doses obtained during the SAR-measurement should show a large scatter. But all investigated OSL samples show very low scatter and a normal distribution indicating fully bleached samples. The obtained OSL-ages (Tab. 7 and 8) are in agreement with radiocarbon dating, pollenanalysis and archeological investigations in that area.

\subsection{Radiocarbon dating}

In this study humic-rich material from a depth of $108 \mathrm{~cm}$ below surface was taken for radiocarbon dating. The specific activity of ${ }^{14} \mathrm{C}$ was measured radiometrically by proportional counters (GEYH 2005). The conventional age is given with a 2-sigma standard deviation and was calculated into calibrated age using Calib 5.0.1 based on STUIVER \& REIMER (1993). For terrestrial material the dataset intcal04 (REIMER et al. 2004) was used and the calibrated ${ }^{14} \mathrm{C}$-age is in the 2-sigma range. The ${ }^{14} \mathrm{C}$-age of sample Hv25552 is $5960 \pm 60$ years BP $\left(\delta^{13} \mathrm{C}=-28.7\right)$ and the calibrated age is cal BC 5081 - 4551 (Early Neolithic, Linear Pottery culture) (Tab.7). 


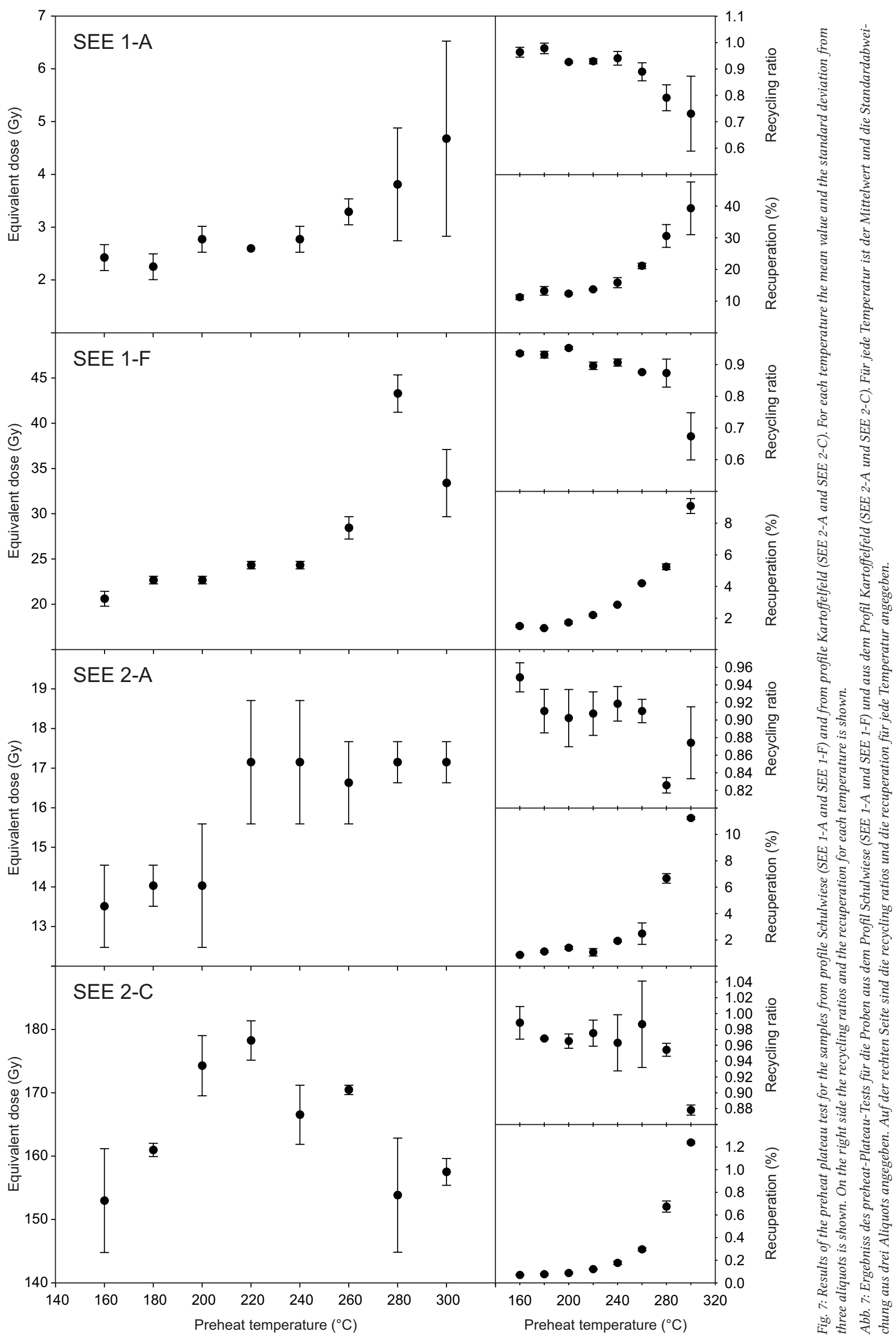


SOM \%

C \%

$\mathrm{N} \%$

$\mathrm{C} / \mathrm{N} \%$

$\mathrm{pH} \mathrm{CaCl}{ }_{2}$

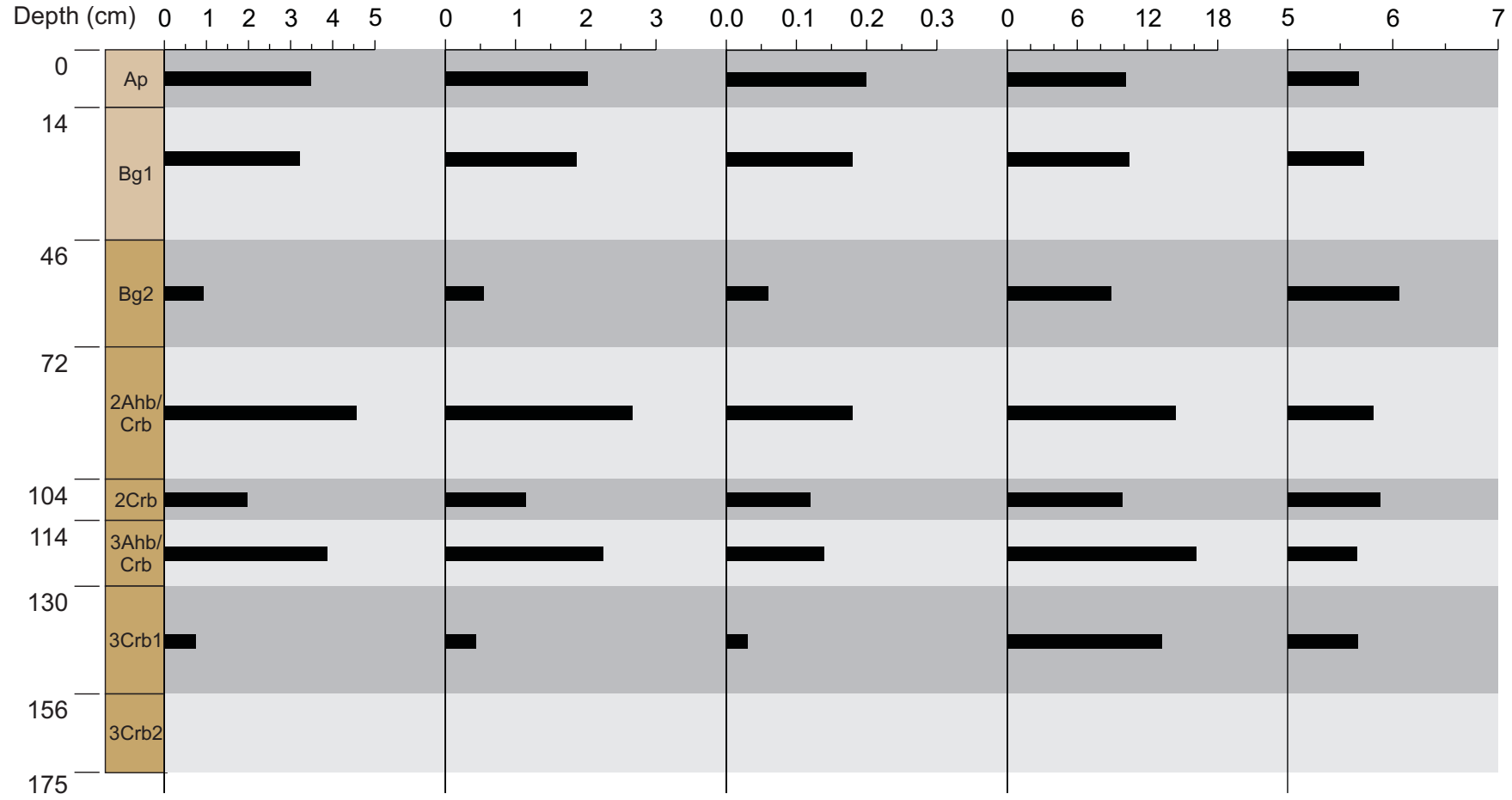

Fig. 8: Soil properties of profile Schulwiese (Seedorf, Lower Saxony).

Abb. 8: Bodeneigenschaften des Profils Schulwiese (Seedorf, Niedersachsen).

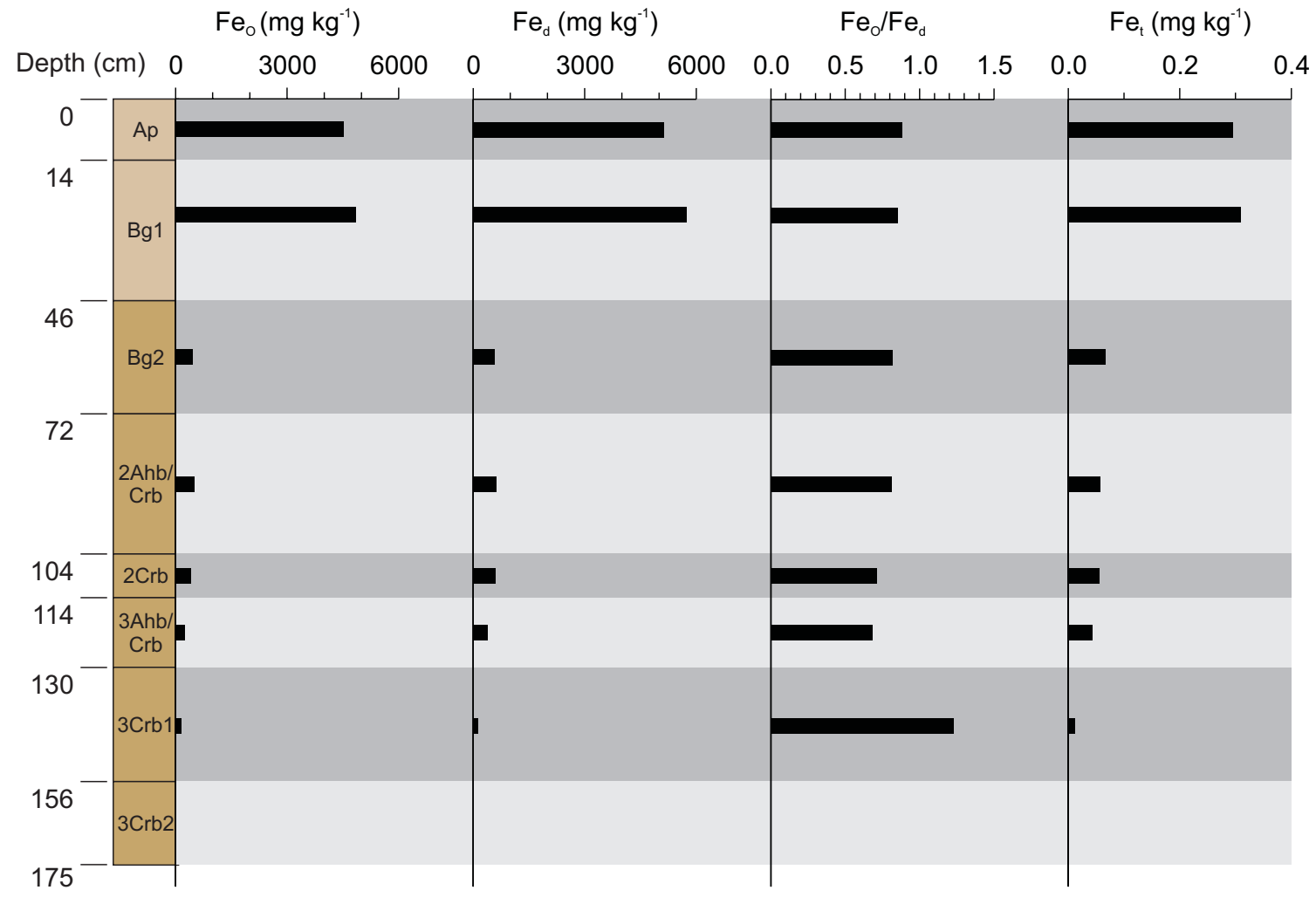

Fig. 9: Total Fe and pedogenic $F_{e}$-oxides of profile Schulwiese (Seedorf, Lower Saxony).

Abb. 9: Verteilung von Eisen $\left(F_{e}\right)$ und pedogenen Eisenoxiden im Profil Schulwiese (Seedorf, Niedersachsen). 


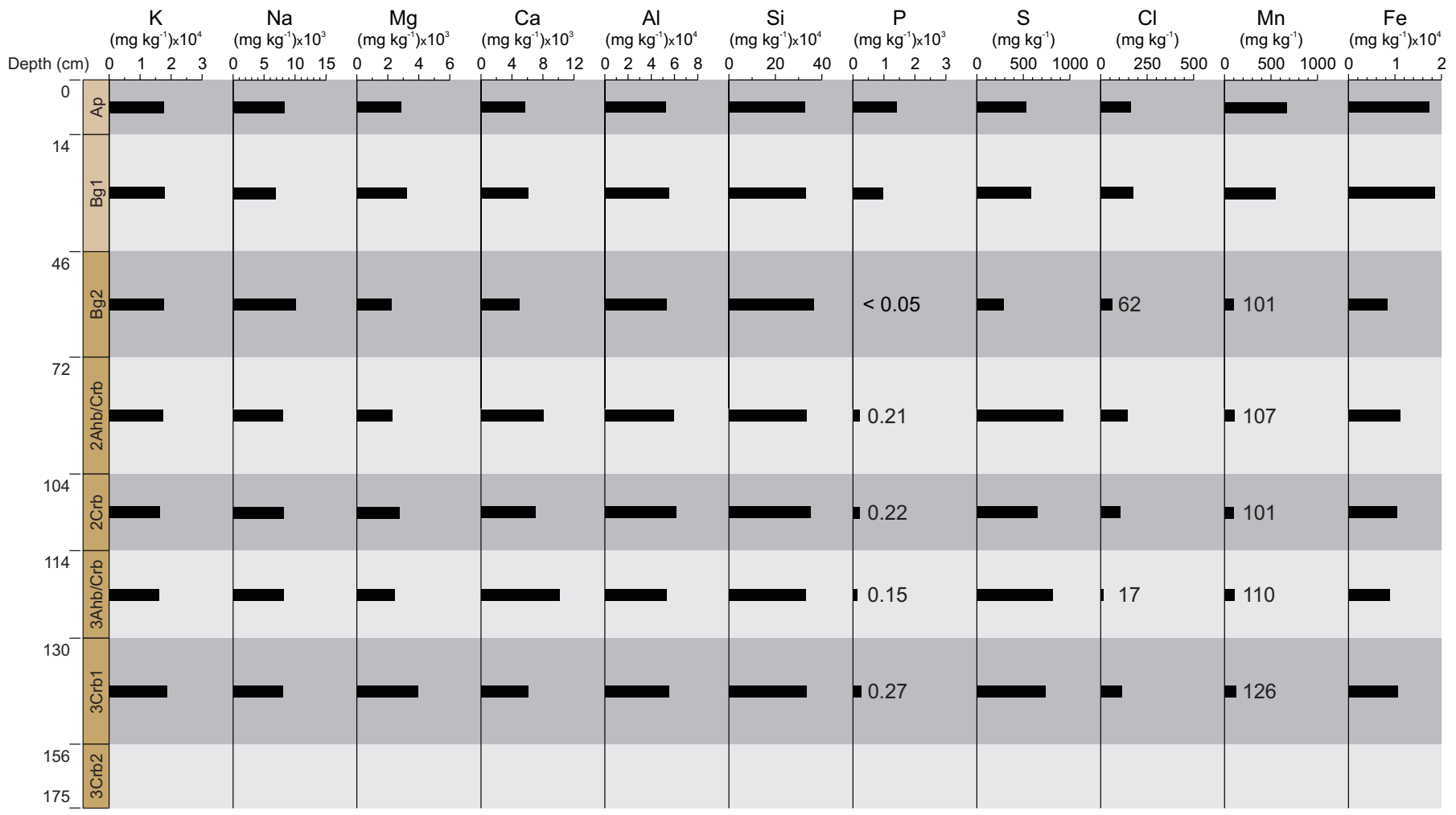

Fig. 10: Major and trace element analysis of profile Schulwiese (Seedorf, Lower Saxony).

Abb. 10: Verteilung von Haupt- und Spurenelementen im Profil Schulwiese (Seedorf, Niedersachsen).

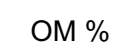

C \%

$\mathrm{N} \%$

$\mathrm{C} / \mathrm{N} \%$

$\mathrm{pH} \mathrm{CaCl}{ }_{2}$

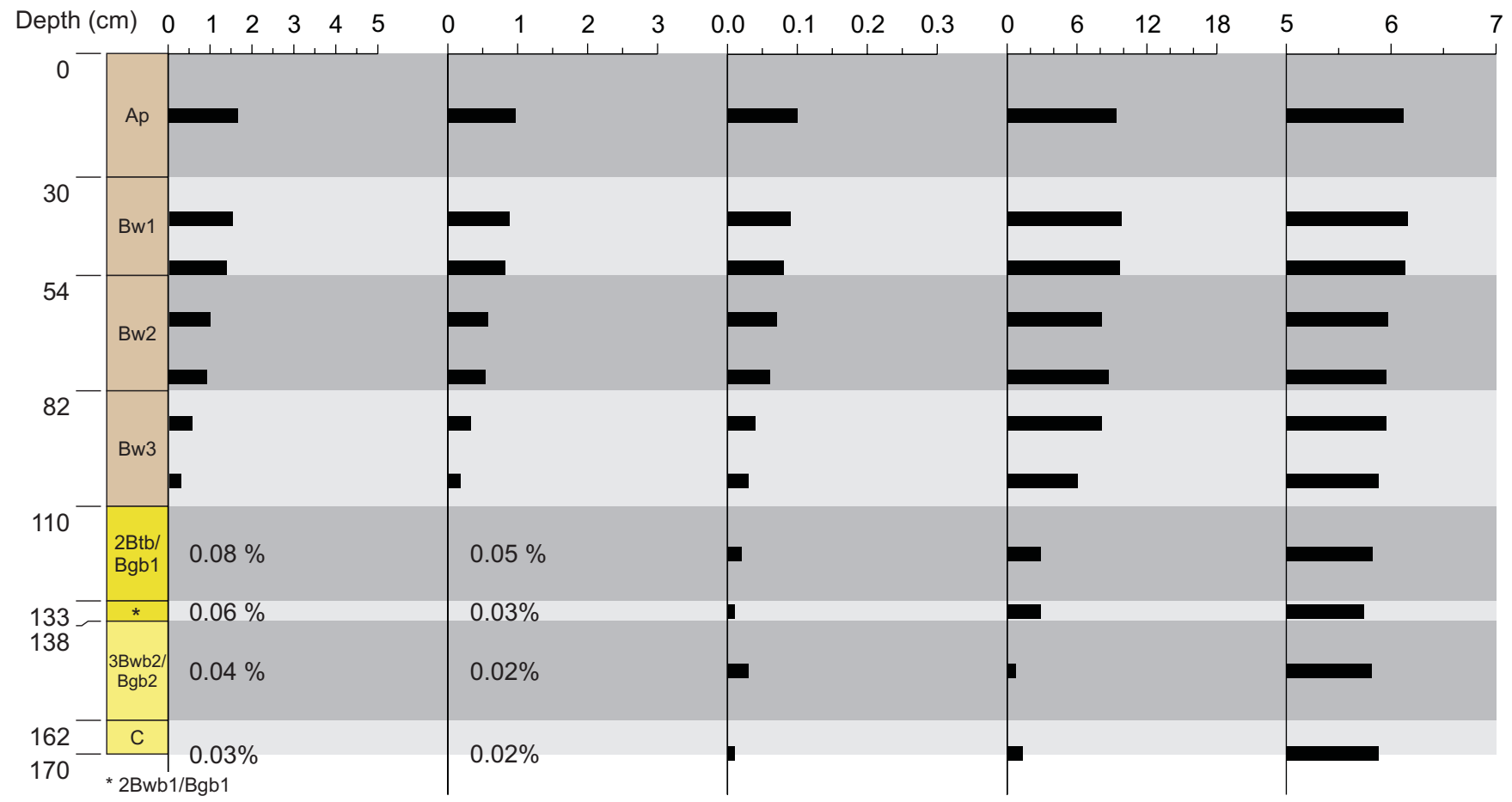

Figure 11: Soil properties of profile Kartoffelfeld (Seedorf, Lower Saxony).

Abbildung 11: Bodeneigenschaften des Profils Kartoffelfeld (Seedorf, Niedersachsen). 
Table 6: Pollen assemblages and Holocene climatic zones of profile Schulwiese (Seedorf, Lower Saxony).

Tabelle 6: Pollenzonen und klimatische Gliederung des Holozän für das Profil Schulwiese (Seedorf, Niedersachsen).

\begin{tabular}{|c|c|c|c|}
\hline $\begin{array}{l}\text { Local pollen assem- } \\
\text { blage Zone, LPAZ }\end{array}$ & Soil horizons & Pollen, Vegetation & Climatic Zones \\
\hline S5 & $\mathrm{Bg} 1$ & Quercus increasing, Alnus, terrestrial herbs, Cerealia & \multirow{2}{*}{$\begin{array}{l}\text { Late Subatlantic } \\
\text { Early Subatlantic }\end{array}$} \\
\hline S4 & $\mathrm{Bg} 2$ & $\begin{array}{l}\text { Alnus, dominance of Poaceae and terrestrial herbs, Cichoria- } \\
\text { ceae, Cerealia and Secale [reye] }\end{array}$ & \\
\hline S3b & $\mathrm{Bg} 2$ & $\begin{array}{l}\text { Decrease of Alnus, strong increase of heliophytes and Poa- } \\
\text { ceae, continuous curve of Cereals }\end{array}$ & \multirow{2}{*}{ Subboreal } \\
\hline S3a & $2 A h b / C r b$ & Alnus, Quercus, Poaceae, slight increase of Cyperaceae & \\
\hline S2 & 2Crb & $\begin{array}{l}\text { Alnus, Quercus, Tilia, Ulmus, Betula, Pinus, Polypodiaceae, } \\
\text { Poaceae increasing }\end{array}$ & Atlantic \\
\hline S1 & 3Ahb/Crb & Betula, Pinus, Selaginella selaginoides & $\begin{array}{l}\text { Boreal } \\
\text { Preboreal }\end{array}$ \\
\hline
\end{tabular}

$\mathrm{Fe}_{\mathrm{O}}\left(\mathrm{mg} \mathrm{kg}^{-1}\right)$

$\mathrm{Fe}_{\mathrm{d}}\left(\mathrm{mg} \mathrm{kg}^{-1}\right)$

$\mathrm{Fe}_{\mathrm{o}} / \mathrm{Fe}_{\mathrm{d}}$

$\mathrm{Fe}_{\mathrm{t}}\left(\mathrm{mg} \mathrm{kg}^{-1}\right)$

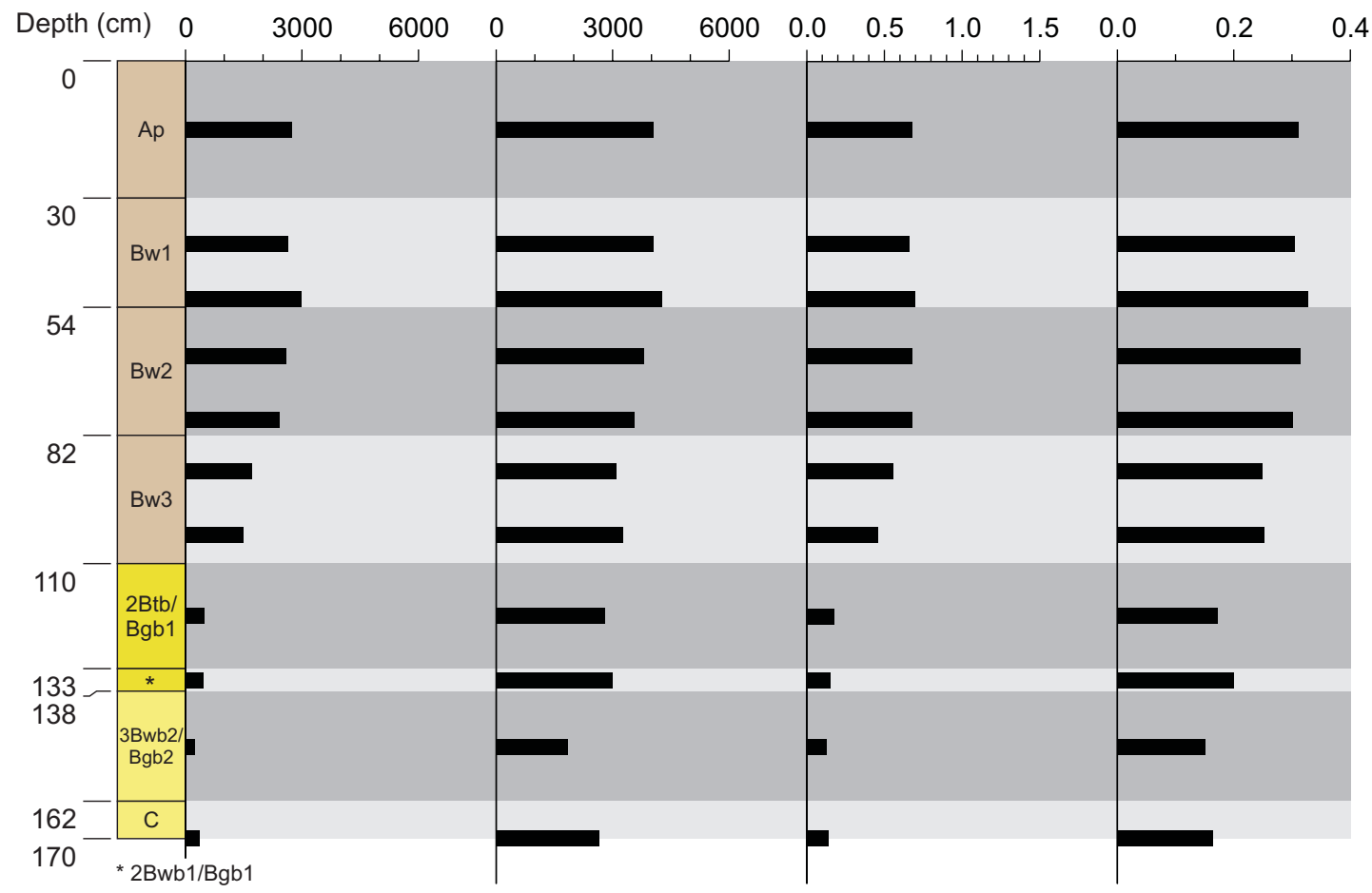

Fig. 12: Total $F_{e}$ and pedogenic $F_{e}$-oxides of profile Kartoffelfeld (Seedorf, Lower Saxony).

$A b b .12$ : Verteilung von Eisen $\left(F_{e}\right)$ und pedogenen Eisenoxiden im Profil Kartoffelfeld (Seedorf, Niedersachsen). 
Table 7: Late Glacial and Holocene climate, dating, archaeological periods and soil development (profile Schulwiese, Seedorf, Lower Saxony). Sampling points for OSL dating are marked by black crosses. White cross marks the sampling position for radiocarbon dating. Soil description is based on IUSS (2006) and in brackets on KA 5 (2005). Soil horizons 3 Crb1 and 3Crb2 are covered by groundwater and not visible in the picture.

Tabelle 7: Spätglaziale und holozäne Klimaentwicklung, Datierungsergebnisse, archäologische Perioden und Bodenentwicklung für das Profil Schulwiese in Seedorf(Niedersachsen). Probennahmepunkte für die OSL-Datierung sind mit schwarzen Kreuzen markiert. Weisse Kreuze markieren den Probennahmepunkt für die Radiokarbondatierung. Die Beschreibung der Bodenhorizonte ist nach IUSS (2006) und in Klammern nach KA 5 (2005). Bodenhorizonte a Gr im Liegenden sind durch Grundwasser bedeckt und im Foto nicht sichtbar.

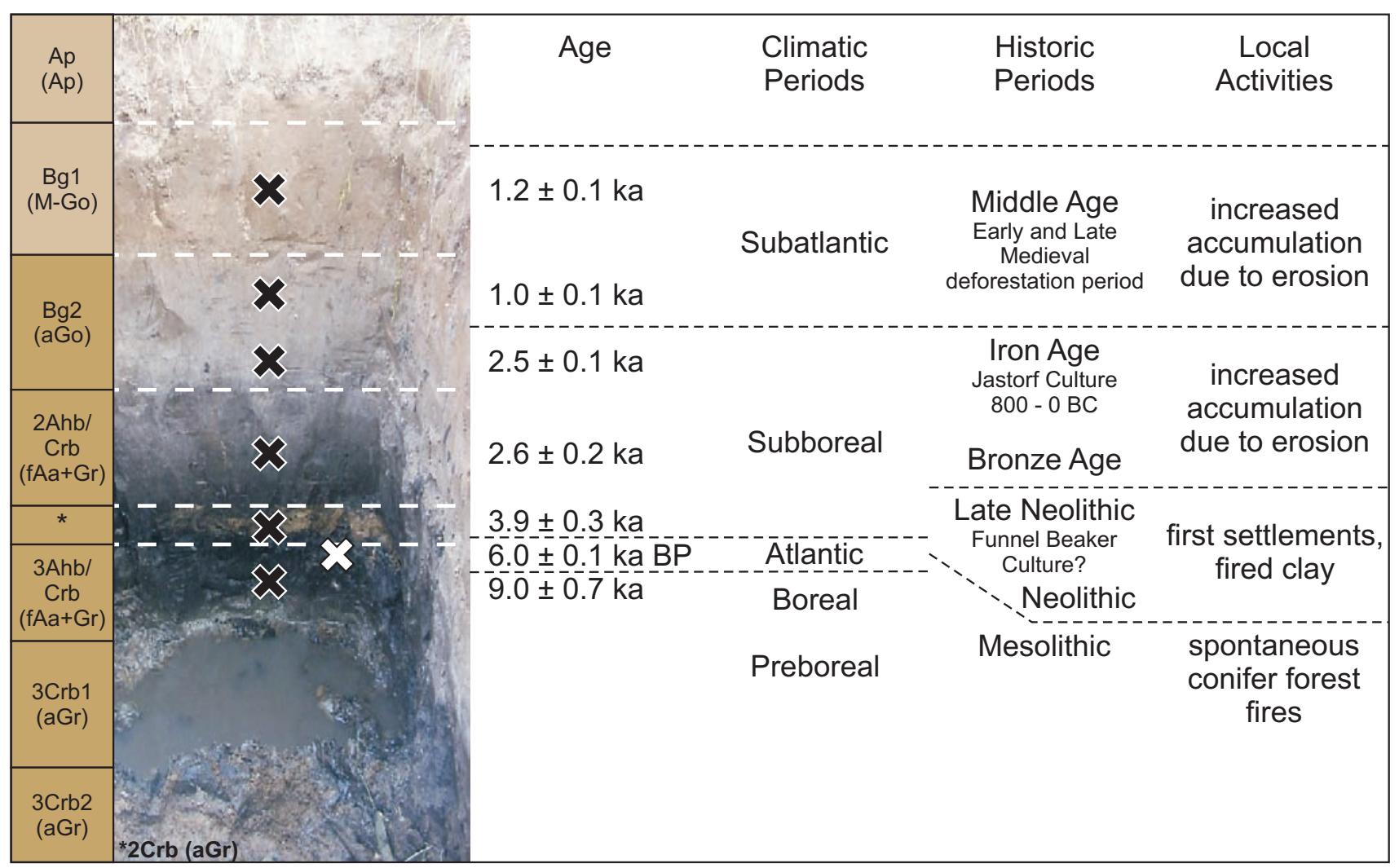

\subsection{Palynology}

The results of 23 samples of profile Schulwiese $(130 \mathrm{~cm}-37 \mathrm{~cm})$ containing between 200 and 580 palynomorphs per count and abundant in micro charcoal are presented in a pollen diagram (Fig. 13). The diagram is subdivided into 5 local pollen assemblage zones (LPAZ) S1-S5, while one zone, LPAZ S3, is further divided into subzones $3 \mathrm{a}$ and $3 \mathrm{~b}$.

LPAZ S1 (130-117.5 cm; horizon $3 \mathrm{Ahb} / \mathrm{Crb})$ is characterized by high values for Betula, Alnus and Pinus; pollen of Ephedra fragilis and spores of Selaginella selaginoides indicate relatively open stands characteristic for early Holocene conditions. Pollen of Quercus, Corylus and Ulmus at the base of the pollen zone might be reworked. The micro charcoal curve peaks in the lower most sample which is probably due to lightning or spontaneous combustion of the conifer (Pinus) dominated woodland rather than pointing to human activities (KALIs et al. 2003). Based on the pollen assemblage the parent material and horizon 3Ahb/ Crb most probably developed during the Preboreal-Boreal transition.

The pollen assemblage of LPAZ S2 (117.5-102.5 cm; upper part of horizon $3 \mathrm{Ahb} / \mathrm{Crb}$, horizon $2 \mathrm{Crb}$, lowest part of $2 \mathrm{Ahb} / \mathrm{Crb}$ ) is dominated by Alnus whereas Betula has decreased, followed by Pinus and Corylus, Quercus, Ulmus and Tilia among the arboreal taxa (AP). Fern spores as well as pollen of Alnus and Betula and of herbs like Filipendula point to a swampy temporarily flooded environment and a high groundwater level. Pollen of other terrestrial heliophilous herbs like Asteraceae, Apiaceae, Caryophyllaceae, Cichoriaceae and Rosaceae are indicative of local open meadows at site Schulwiese. The increasing curve of grass pollen (Poaceae) and a peak in the generally high charcoal curve observed in horizon $2 \mathrm{Crb}$, might point to human activity although anthropogenic indicators are still lacking in this pollen zone. From the pollen assemblage of the woody plants a local back swamp forest with predominantly $\mathrm{Al}$ nus and Betula can be concluded whereas Quercus-UlmusTilia-Corylus woodland was distributed on higher elevated loess stands. Summarizing the pollen assemblage of woody plants of pollen zone S2 (horizon 2Crb) points to an Atlantic age.

This conclusion is supported by a ${ }^{14} \mathrm{C}$-age of cal $\mathrm{BC}$ 5081-4551 obtained from humic material of the $2 \mathrm{Crb}$ $(108 \mathrm{~cm})$ pointing to a younger Atlantic age for upper parts of LPAZ S2 (Tab. 6)

LPAZ S3 is divided into subzone S3a $(102.5-92.5 \mathrm{~cm})$ representative of the lower part of $2 \mathrm{Ahb} / \mathrm{Crb}$ horizon and subzone S3b $(92.5 \mathrm{~cm}-62.5 \mathrm{~cm})$ which characterizes the upper part of the $2 \mathrm{Ahb} / \mathrm{Crb}$ and the lower part of $\mathrm{Bg} 2$ horizons. LPAZ $3 \mathrm{a}$ is still characterized by high amounts of AP, mainly of Alnus, Quercus, Pinus, Tilia and Corylus. The Poaceae curve increases towards the boundary with subzone S3b and a slight increase of Cyperaceae is observed as well as 


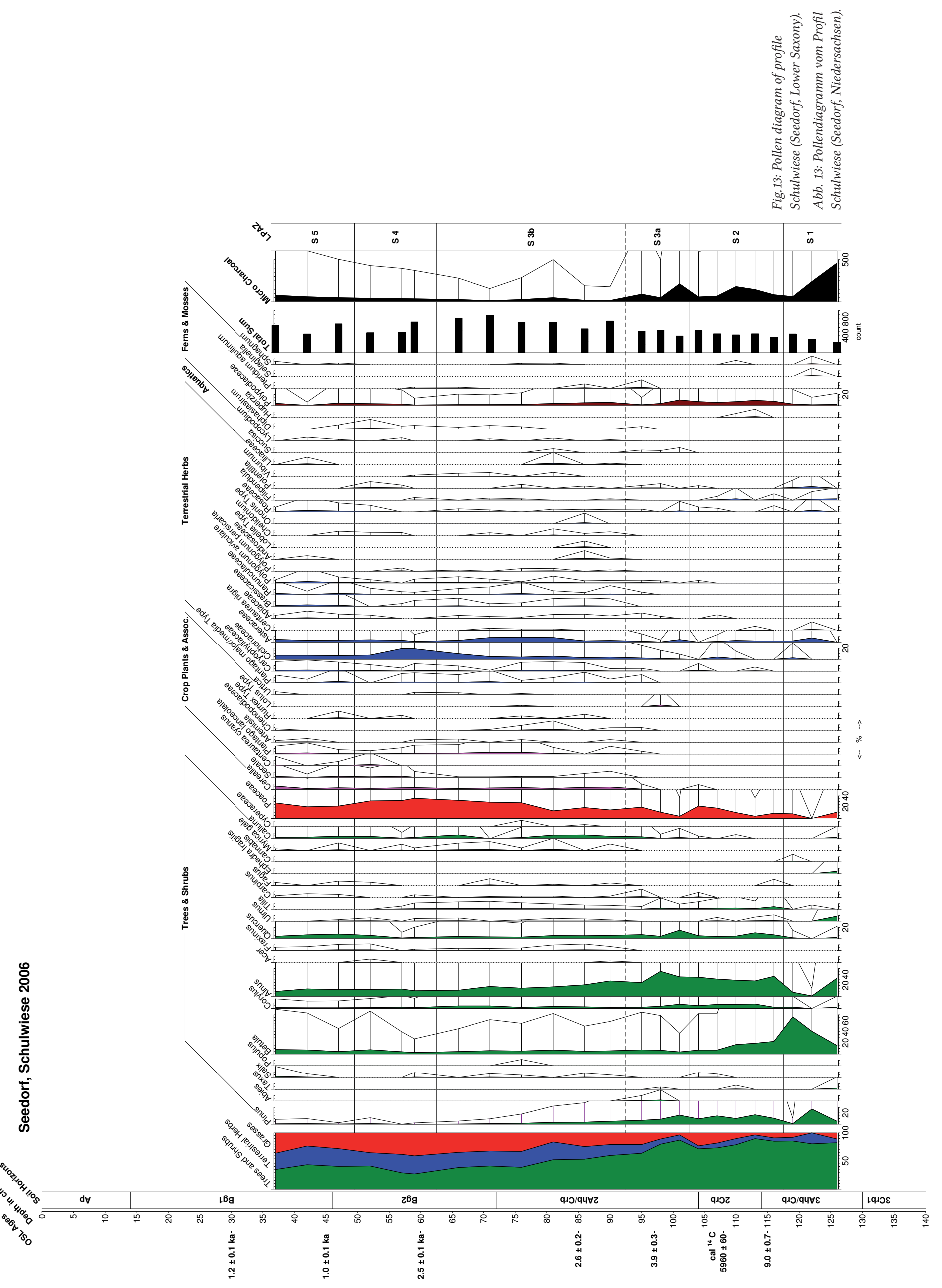


Table 8: Late Weichselian and Holocene climate, dating, archaeological periods and soil development (profile Kartoffelfeld, Seedorf, Lower Saxony). Sampling points for OSL dating are marked by black crosses. Soil description is based on IUSS (2006) and in brackets on KA 5 (2005).

Tabelle 8: Spätweichselzeitliche und holozäne Klimaentwicklung, Datierungsergebnisse, archäologische Perioden und Bodenentwicklung für das Profil Kartoffelfeld in Seedorf (Niedersachsen). Probennahmepunkte für OSL-Datierung sind mit schwarzen Kreuzen markiert. Die Beschreibung der Bodenhorizonte ist nach IUSS (2006) und in Klammern nach KA 5 (2005).

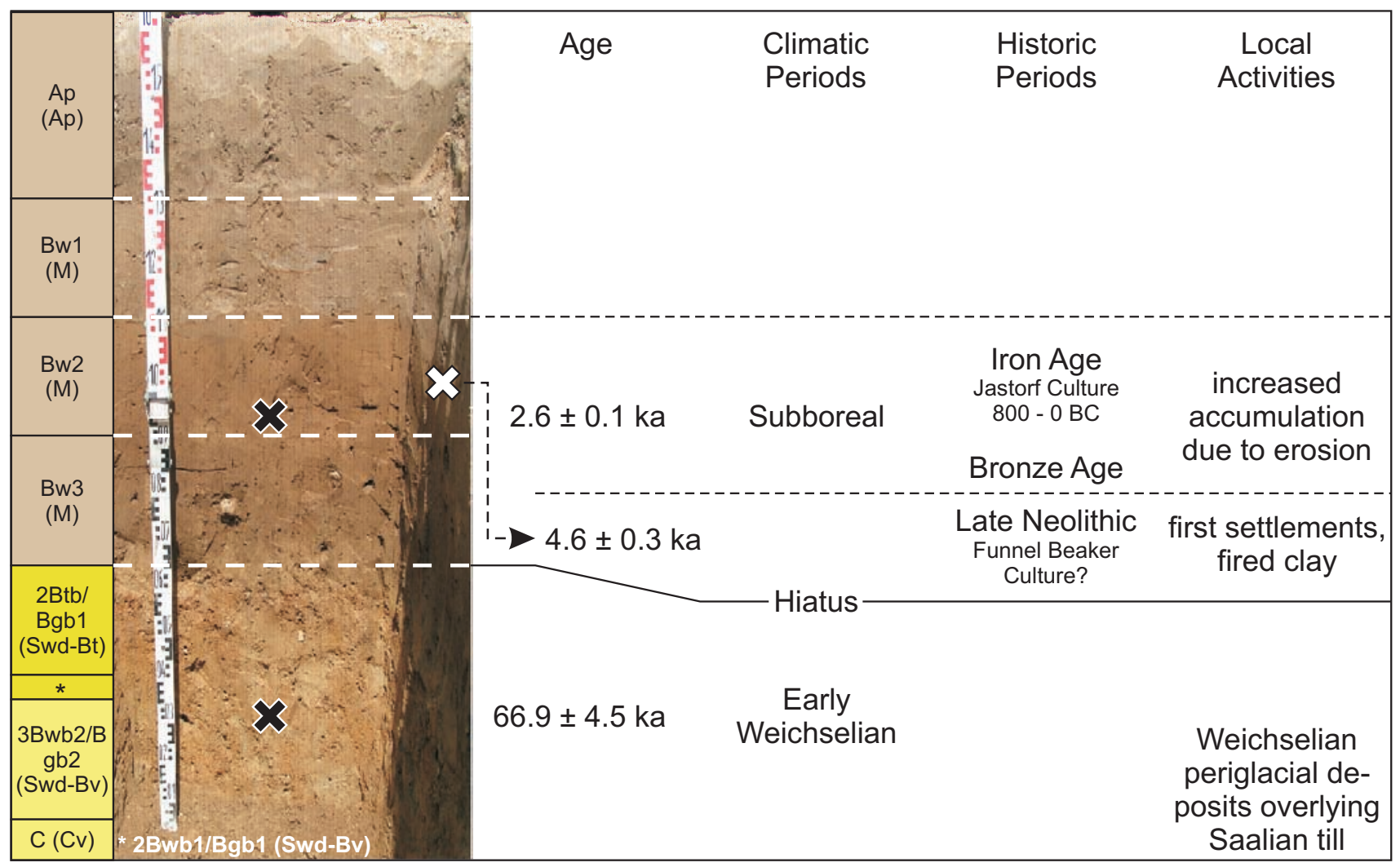

an increase of the heath Calluna. In the same levels (lower part of LPAZ $3 \mathrm{a}$ and 2Ahb/Crb horizon) a fresh thin alluvial loess layer with fired clay and two peaks in the charcoal curve point to earliest human environmental impact in the study area.

During LPAZ S3b a decrease in arboreal pollen in particular of Pinus and a strong increase of heliophytes and Poaceae is observed accompanied by the continuous presence of Cerealia pollen and frequent occurrence of other anthropogenic indicators like Plantago lanceolata, Plantago major/media Type, Artemisia, Rumex and Chenopodiaceae (BEHRE 1981) and a further increase of Calluna. A Subboreal age can be concluded from the pollenspectra for LPAZ S3a whereas LPAZ S3b reveals a phase of intensive land use activities of late Subboreal, early Subatlantic times.

The OSL age of $3.9 \pm 0.3 \mathrm{ka}$ at the layer of fired clay in $97 \mathrm{~cm}$, most probably indicates Late Neolithic cultural activities in the area of Seedorf during pollen subzone S3a (Tabs. 6, 7 and 8). The OSL age obtained from sample SEE 1-C $(85 \mathrm{~cm})$ (Tab. 3) of LPAZ S3b is around $2.6 \mathrm{ka}$ and indicates a Late Subboreal age (Tab. 6) with evidence for Late Bronze Age to Iron Age settlement activities.

LPAZ S4 $(62.5-49 \mathrm{~cm})$ comprises the middle and upper part of the $\mathrm{Bg} 2$ horizon. It is characterized by a nearly total lack of Pinus, the dominance of Poaceae and terrestrial herbs, Cichoriaceae, Cerealia and the first occurrence of Secale (rye) pollen. Summer rye cultivation on sandy soils of Northern Germany since the Roman Iron Age has been demonstrated re- peatedly by BEHRE (2000). Its regular cultivation in the study area since the $2^{\text {nd }}$ century after Christ $(\mathrm{AC})$ is known from archaeobotanical investigations of excavated sites by KIRLEIS (2003) and from peat bog pollen studies for northeast Lower Saxony (Kirleis 2003, BECKer \& URBAN 2006). The OSL age of $2.5 \pm 0.1 \mathrm{ka}$ from $60 \mathrm{~cm}$ depth is in agreement with the Early Subatlantic pollenspectra indicative for ongoing land use activities and early rye cultivation.

LPAZ S5 (49-36.5 cm) is the youngest pollen zone describing the uppermost part of $\mathrm{Bg} 2$ and the lower and middle parts of the colluvial horizon Bg1. The upper part of this horizon as well as the Ap horizon have not been sampled for pollen and age determination because of ploughing and other land use activities in the valley. The local pollen assemblages are similar to those of LPAZ S4 except for increasing Quercus values and a richer heliophilous herb flora. The OSL ages for LPAZ S5 of $1.2 \pm 0.1 \mathrm{ka}$ and $1.0 \pm 0.1 \mathrm{ka}$ from $45 \mathrm{~cm}$ and $60 \mathrm{~cm}$ depth for the colluvium and the underlying Bg2 horizon (Tabs. 6, 7 and 8) are indicating another intensive accumulation phase which can be related to the Middle Age deforestation period (Tab. 9).

\section{Discussion and Conclusion}

In contrast to the loess areas in Germany (summarised in GeHrt 2000 and EcKmeIER et al. 2007) little is known on the environmental history and role of people in soil-sediment genesis of the particular sand loess study area in the central Lüneburg Heathland. 


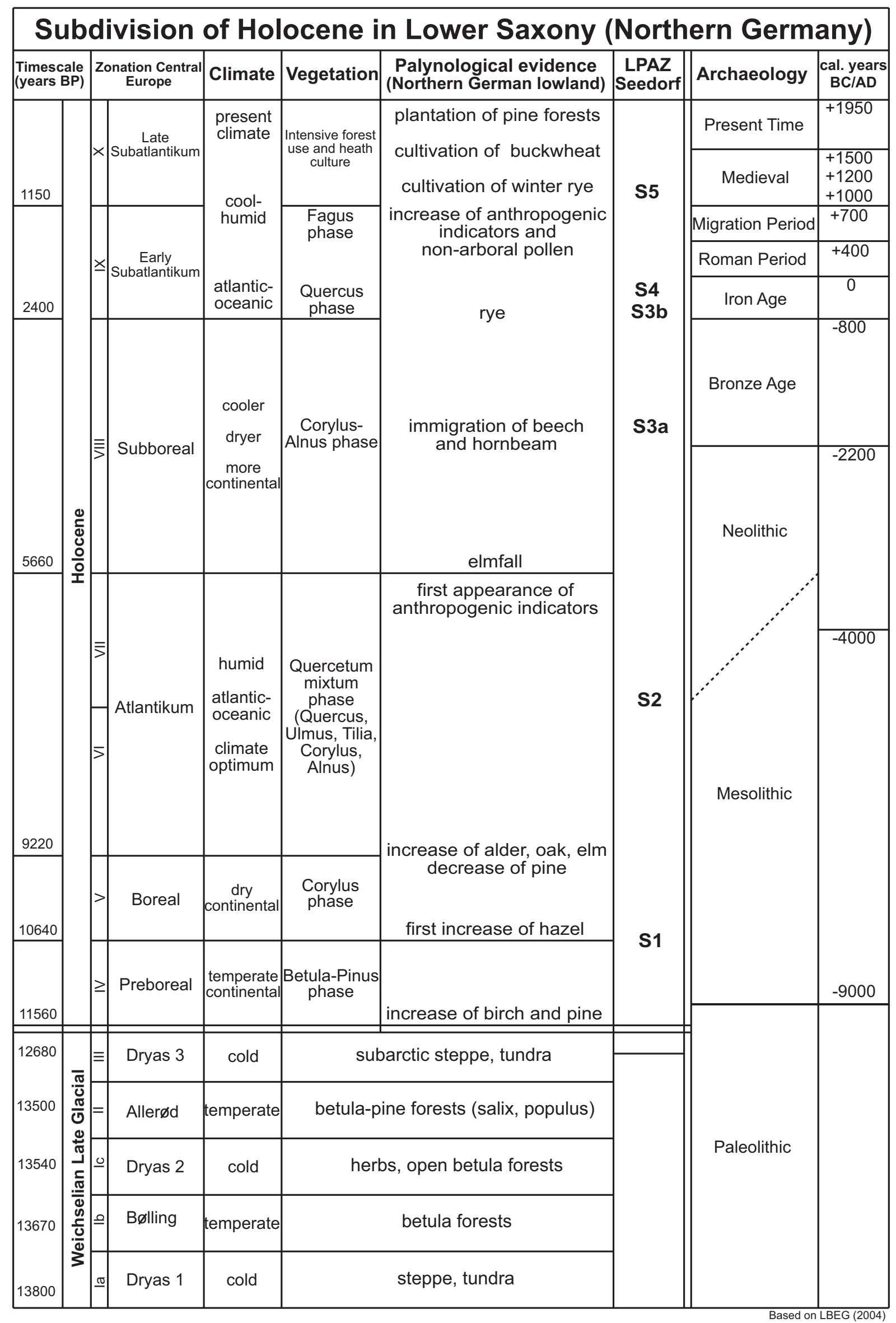

Table 9: Late Glacial and Holocene climate, vegetation, archaeological periods and local pollen assemblage zones of soil-sediment profile Schulwiese (Seedorf, Lower Saxony) (after FIRBAS, 1949, IVERSEN 1954, LITT et al., 2003).

Tabelle 9: Spätglaziale und holozäne Klimazonen, Vegetationszonen, archäologische Perioden und lokale Pollenzonen für das Profil Schulwiese in Seedorf (Niedersachsen) (nach FIRBAS, 1949, IVERSEN 1954, LITT et al., 2003) 
By comparing textures of the loess colluvials of the investigated profiles with other sand loess deposits in Northern Germany and proximal areas (Fig. 14), it can be shown that the texture of Gleysol/Colluvisol Schulwiese reveals clayey, sandy silt whereas the Colluvisol/Stagnic Luvisol Kartoffelfeld has slightly higher sand content. Those differences are most probably due to the different depositional environments of site Schulwiese in a small flood plain and of the second higher elevated gently sloping plateau site Kartoffelfeld (Figs. 2 and 4). All horizons developed on colluvium as well as the buried A horizons situated in the valley bottom, are rich in organic Carbon and Nitrogen as well as in free Iron, which is indicative of the loess-soil borne younger material. Profile Schulwiese situated at the valley bottom at the margin of a small flood plain experienced at least three phases of relative unstable land surface and accumulation phases respectively.

The pollen assemblage zones do not reflect a continuously deposited sediment record, but the analysed pollen and spore assemblages derive from periods of temporary flooding, phases of pedogenetic processes under stable land surface as well as reflecting hiatuses caused by erosion. OSL ages and palynological data refer to Preboreal-Boreal times for the development of horizon $3 \mathrm{Ahb} / \mathrm{Crb}$ and its parent material (Tab. 7). The radiocarbon age of cal BC 5081-4551 for horizon Crb2 and palynological results indicate a mid- dle-younger Atlantic age. The OSL age of $3.9 \pm 0.3 \mathrm{ka}$ at the slightly higher level of $97 \mathrm{~cm}$ (horizon 2Ahb/Crb and 2Crb) suggests an early Subboreal age for the accumulation and soil development phase and dates the palynological evidence of Late Neolithic land use activities in the area of Seedorf (Fig. 13, Tabs. 6, 7 and 8). Roeschmann (in Kuntze et al. 1994) described soil development, erosion and accumulation of colluvium in the Northern German scattered sand loess areas as a product of initial Neolithic anthropogenically induced environmental changes. There is evidence of the Late Neolithic Funnel Beaker culture (3300-2700 BC, HEGE \& MAIER 1991) for the area southwest and east of Lüneburg (Sprockhoff 1975, SCHIRNig 1979, Assendorp 1999) in the close vicinity to the study sites of Seedorf. Calluna (heather) is recorded from local pollen assemblage zone S3a as well as Cerealia pollen. BECKER \& URBAN (2006) demonstrated temporary expansion of heathland as a consequence of agricultural land use and woodland pasture occurring during the latest Neolithic period at the beginning of the Bronze Age and in Medievel times for the southern part of the County of Uelzen.

The two OSL ages obtained from $85 \mathrm{~cm}$ and $60 \mathrm{~cm}$ (Tabs. 3 and 7) of around $2.6 \mathrm{ka}$ date the local pollen assemblage zone S3b, which reveals a phase of intensive land use and consequently sediment accumulation due to erosion from settlement activities of Late Bronze and Iron Age cultural groups

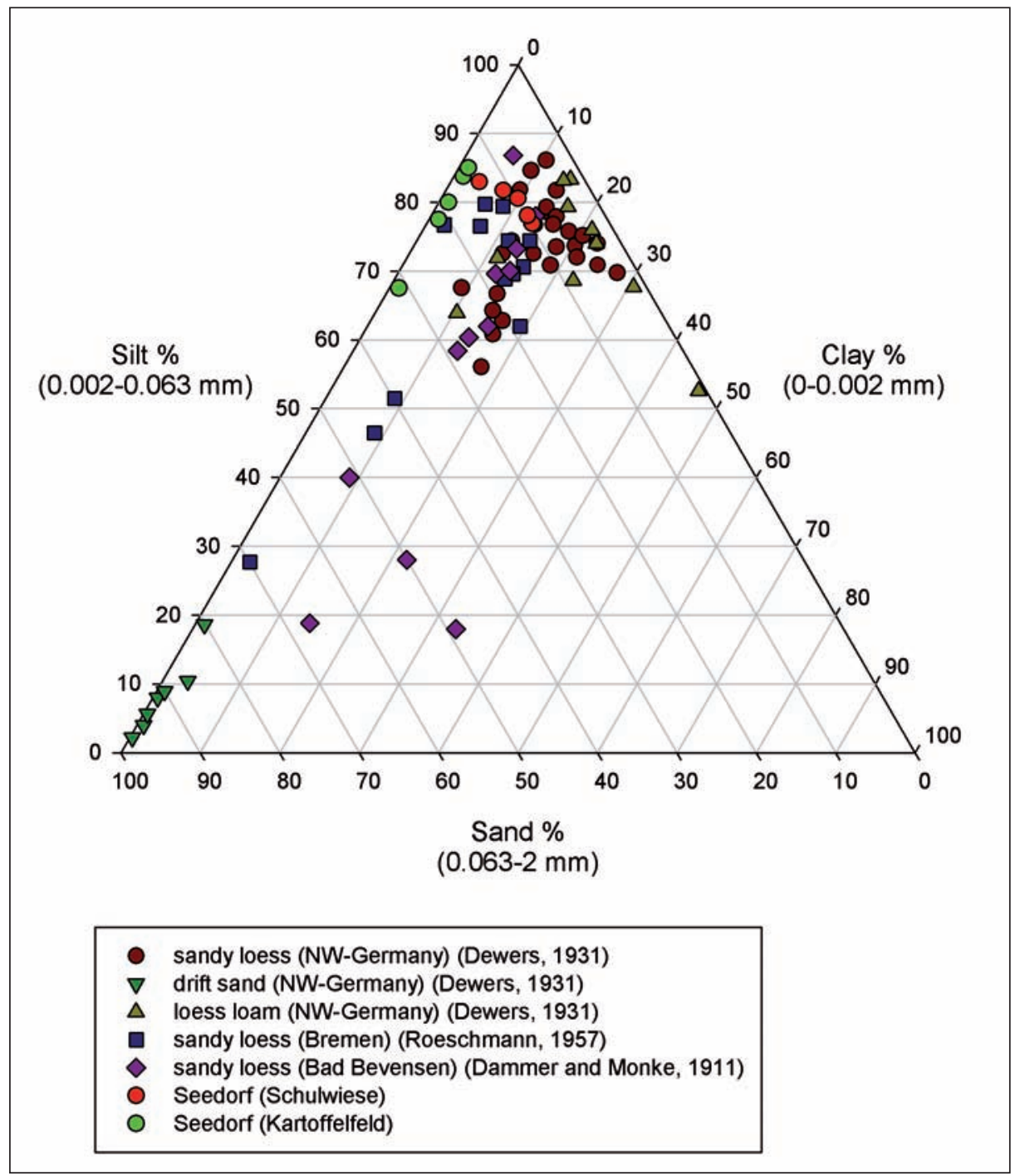

Fig. 14: Soil texture triangle showing different sand and loess sites in Northern Germany in relation to texture characteristics of profiles Schulwiese and Kartoffelfeld (Seedorf, Lower Saxony).

Abb. 14: Zusammenstellung verschiedener Proben aus Sand- und Sandlössgebieten in Norddeutschland und vergleich mit den Korngrössenuntersuchungen aus den Profilen Schulwiese und Kartoffelfeld (Seedorf, Niedersachsen). 
(Tabs. 6, 7 and 9). As there is local (Seedorf Cultural Stage, SCHWANTES 1952) and regional archaeological evidence of widespread Iron Age settlements attributed to the Jastorf culture (600-0 BC, HäsSLER 1991), this part of the profile Schulwiese clearly derives from a phase of intensive anthropogenic impact on the Late Subboreal/Early Subatlantic landscape, which is as well recorded from pollen diagrams of peat bogs and archaeobotanical investigations of sites close by (KIRLEIS 2003). Unexpected observations were made for the colluvial accumulation of Bw3 and Bw2 horizons of profile Kartoffelfeld (Tab. 8), which have been OSL dated to 4.6 ka and 2.6 ka corresponding most probably to the same Late Neolithic and Iron Age cultural periods, the latter one attributed to the Jastorf culture, found as well in profile Schulwiese (Tab. 7).

The latest severe erosional phase which resulted in the colluvium of profile Schulwiese (Tabs. 7 and 9, Fig. 12) was OSL dated to around $1 \mathrm{ka}$ and corresponds with the Early and Late Medieval deforestation period, which is not recorded in the pollen diagram but well known from other research. BoRk et al. (1998) describe a reduction of forest cover in Germany up to $17 \%$ at the time of $1300 \mathrm{AD}$ due to extensive expansion of arable land.

The OSL age of $66.9 \pm 4.5 \mathrm{ka}$ for the parent material of horizons 2Bwb1/Bgb1and 2Btb/Bgb1 of sequence Kartoffelfeld points to an Early Weichselian depositional phase of sandy silty material and gives additional information about erosion processes since that time.

The results show evidence of human impact on soil development since the Neolithic which is shown by the black horizon in the Schulwiese profile. However, organic horizons are not mandatory for anthropogenic activities. Based on this study human impact on the widely distributed humic soils in the sandy loess area has to be accepted since the late Neolithic Bronze Age transition. ZolitschkA et al. (2003) demonstrated that the first spread of Neolithic cultures in the loess areas of southern Germany was guided by soil quality. Their observations point to a change of that pattern towards the late Neolithic, when agriculture expanded all over and across central Europe, which coincides with the start of cooler and moister climatic conditions. Our results deduced from soil sediment archives suggesting four post-Neolithic main periods, the early Bronze Age, the pre-Roman and the Roman Iron Age and the early to late Medieval of increasing human environmental impact and settlement in the sandy loess region of the Lüneburg Heathland (Tabs. 7, 8 and 9), which are in good accordance with findings made in colluvial, fluvial and lacustrine archives of other reference areas in Germany described by ZoLITsCHKA et al. (2003).

More work on other sites of the Lüneburg Heathland is required to prove and refine our results and furthermore to separate the humic horizons from modern Plaggen soils.

\section{Acknowledgements}

We thank Christiane Hilmer, Suderburg for valuable help with laboratory treatment of the samples and soil analyses and Katrin Becker for her assistance with the palynological work. We are very thankful to Mario Tucci, Suderburg who helped draft graphs and figures. We finally like to thank
Professor Peter Kershaw, Monash University, Australia for correcting the English manuscript and the two reviewers for their valuable advice.

\section{References}

AdAmiec, G. \& Aitken, M. (1998): Dose-rate conversion factors: update. Anc. TL, 16: 37-50; Aberystwyth.

Aitken, M. J. (1998): An introduction to optical dating. - 267 S.; Oxford (Oxford University Press).

AssendoRP, J.J. (1999): Die Häuser der Trichterbecherkultur in Nordostniedersachsen. - Ber. Denkmalpfl. Niedersachs., 19: 180-185; Hameln.

BEckeR, K. (1995): Paläoökologische Untersuchungen in Kleinmooren zur Vegetations- und Siedlungsgeschichte der zentralen Lüneburger Heide. - 159 S.; Diss. Univ. Hannover.

BECKER, K. \& URBAN, B. (2006): Jungholozäne Umweltentwicklung und Landnutzungsgeschichte im Hardautal, Ldkr. Uelzen (südliche Lüneburger Heide). - TELMA, 36: 11-38; Hannover.

BeHre, K.-E. (1981): The interpretation of anthropogenic indicators in pollen diagrams. - Pollen et Spores, 23: 225-245; Paris.

BeHre, K.-E. (2000): Frühe Ackersysteme, Düngemethoden und die Entstehung der nordwestdeutschen Heiden. - Arch. Korrbl., 30: 135-151; Mainz.

Beug, H.-J. (2004): Leitfaden der Pollenbestimmung für Mitteleuropa und angrenzende Gebiete. - 542 S.; München (Pfeil-Verlag).

Blume, H.-P. \& Leinweber, P. (2004): Plaggen Soils: landscape history, properties, and classification. - J. Plant Nutr. Soil Sci., 167: 319-327.

Bork, H.-R., Bork, H., Dalchow, C., Faust, B., Piorr, H.-P. \& Schatz, T. (1998): Landschaftsentwicklung in Mitteleuropa. - 328 S.; Gotha (Klett-Perthes).

Caspers, G., Jordan, H., Merkt, J., Meyer, K.-D., Müller, H. \& Streif, H. (1995): Niedersachsen. In: Benda, L. (Hrsg.): Das Quartär Deutschlands: 23-58; Stuttgart (Borntraeger).

Chen, C.-T. A., Wann, J.-K. \& Lou, J.-Y. (2001): Aeolian flux of metals in Taiwan in the past 2600 years. - Chemosph., 43: 287-294; Amsterdam.

DAmmer, B. \& Monke, H. (1911): Erläuterungen zur Geologischen Karte von Preußen und benachbarten Bundesstaaten - Blatt Bienenbüttel. 67 p.; Berlin (Königlich Preußische Geologische Landesanstalt).

Dewers, F. (1932): Flottsandgebiete in Nordwest-Deutschland, Ein Beitrag zum Lössproblem. - Abh. Naturwiss. Ver. Bremen, 28: 131-204; Bremen

Eckmeier, E., Gerlach, R., Gehrt, E. \& Schmidt, M.W.I. (2007): Pedogenesis of Chernozems in Central Europe - a review. Geoderma, 139: 288-299; Amsterdam.

FAegri, K. \& Iversen, I. (1989): Textbook of pollen analysis. - 338 p.; London (John Wiley \& Sons).

Fiedler, H. J. \& Altermann, M. (1964): Verbreitung, Entstehung und Eigenschaften von Sandlöss (Flottsand) im norddeutschen Flachland und angrenzenden Gebieten. - Geologie, 13: 1199-1226; BerliFirbas, F. (1949/52): Spät- und nacheiszeitliche Waldgeschichte Mitteleuropas nördlich der Alpen (2 Bde.). - 480+256 p.; Jena (Fischer).

Frechen, M., Oches, E. A. \& Kohlfeld, K. E. (2003): Loess in Europe mass accumulation rates during the Last Glacial Period. - Quat. Sci. Rev., 22: 1835-1857; Amsterdam.

Frechen, M., SchweItZer, U. \& ZANDER, A. (1996): Improvements in sample preparation for the fine grain technique. - Anc. TL, 14: 15-17; Aberystwyth.

GeEBERs, W. (1995): Fünfzehn Jahre Grabung Rullstorf, eine Bilanz. - Ber. Denkmalpfl. Niedersachs., 6: 65-60; Hameln.

GeHrt, E. (2000): Nord- und mitteldeutsche Lössbörden und Sandlössgebiete. - In: Blume et al. (1995): Handbuch der Bodenkunde, 9. Erg.-Lfg. 10/2000; Weinheim (Wiley-VCH).

Geyh, M. A. (2005): 14C dating - still a challenge for users? - Z. Geomorph. N.F. Suppl., 139: 63-85; Berlin.

GRIMM, E. (1990): TILIA, TILIAGRAPH \& TILIAVIEW. PC spreadsheet and graphics software for pollen data. Illinois State Museum, IL, USA. (http://www.geo.arizona.edu/palynology/geos581/tiliaview.html)

HässLER, H.-J. (1991): Vorrömische Eisenzeit. - In: Häßler, H.-J. (Ed.):Urund Frühgeschichte in Niedersachsen: 193-237; Stuttgart (Theiss).

Hagedorn, J. (1964): Geomorphologie des Uelzener Beckens. - Göttinger geogr. Abh., 31: 200 p. Göttingen

Heege, E. \& Maier, R. (1991): Jungsteinzeit. - In: Häßler, H.-J. (Ed.): Urund Frühgeschichte in Niedersachsen: 109-154; Stuttgart (Theiss).

Holmgren, G.G. (1967): A rapid citrate-dithionite extractable iron procedure. - Soil Sci. Soc. Am. Proc., 31: 210-211; Madison. 
Huntley, D. J. ¿ LAmothe, M. (2001): Ubiquity of anomalous fading in Kfeldspars and the measurement and correction for it in optical dating. - Can. J. Earth Sci., 38: 1093-1106; Ottawa.

IUSS Working Group WRB (2006): World Reference Base for Soil World Resources 2006. - World Soil Resources Report, 103; Rome (FAO).

IvERSEN, J. (1954): Late-Glacial Flora of Denmark and its relation to climate and soil. - Danmarks Geologiske UndersØgelske, II. Række, 80: 87-119; Kopenhagen.

KA5 (2005): AG Boden - Bodenkundliche Kartieranleitung. - 438 S.; Stuttgart (Schweizerbart).

Kalis, A. J., MerkT, J. \& Wunderlich, J. (2003): Environmental changes during the Holocene climatic optimum in central Europe - human impact and natural causes. - Quat. Sci. Rev., 22: 33-79; Amsterdam.

KIRLEIS, W. (2003): Vegetationsgeschichtliche und archäobotanische Untersuchungen zur Landwirtschaft und Umwelt im Bereich der prähistorischen Siedlungen bei Rullstorf, Ldkr. Lüneburg. - Probl. Küstenforsch. südl. Nordseegeb., 28: 65-132; Oldenburg.

Kucz, V. (2006): Erstellung einer bodenkundlichen Bestandsanalyse und Berechnung der Bodenerosion mithilfe der allgemeinen Bodenabtragsgleichung (ABAG) im nördlichen Teil des Landkreises Uelzen, Gemeinde Seedorf. - Diploma Thesis, LEUPHANA University Lüneburg; unpublished.

Kuntze, H., Roeschmann, G. \& Schwerdtfeger, G. (1994): Bodenkunde - 424 S.; Stuttgart (Ulmer).

LANG, H. D. (1974): Uber Verbreitung, Zusammensetzung und Alter des Sandlösses im Raum Wittingen-Hankensbüttel. - Z. Dtsch. Geol. Gesellsch., 125: 269-276; Hannover

LANG, H. D. (1990): Der Sandlöss in der Umgebung von Bergen Krs. Celle - Verbreitung, Zusammensetzung und Entstehung. - Eiszeitalter und Gegenwart, 40: 97-106; Öhringen/Württ.

LitT, T., Schmincke, H.-U. \& Kromer, B. (2003): Environmental response to climate and volcanic events in central Europe during the Weichselian Lateglacial. - Quaternary Science Reviews, 22: 7-32; Oxford.

MAUZ, B. \& LANG, A. (2004): The dose rate of beta sources for optical dating applications: a comparison between fine silt and fine sand quartz. - Anc. TL, 22: 45-48; Aberystwyth.

Mauz, B., Packman, S. \& Lang, A. (2006): The alpha effectiveness in siltsized quartz: new data obtained by single and multiple aliquot protocols. - Anc. TL, 24: 47-52; Aberystwyth.

Moore, P.D.; WebB, J.A. \& Collins, M.E. (1991): Pollen analysis. - 224 S. Oxford (Blackwell Scientific Publications). Munsell Soil Color Charts. Baltimore, U.S.A.

Murray, A. S. $\mho$ WintLe, A. G. (2000): Luminescence dating of quartz using an improved single-aliquot regenerative-dose protocol. - Radiat. Meas., 32: 57-73; Oxford.

Murray, A. S. \& Wintle, A. G. (2003): The single aliquot regenerative dose protocol: potential for improvements in reliability. - Radiat. Meas., 37: 377-381, Oxford.

Page, A. L., Miller, R. H., Kennedy, D. R., Baker, D. E., Ellis, R. \& RHOADES, J. D. (Hrsg.) (1982): Methods of Soil analysis. Part 2. chemical and microbiological properties. - 1159 S., Madison (Soil Science Society of America)

PÉCSI, M. (1990): Loess is not just the accumulation of dust. - Quat. Int., 7/8: 1-21; Amsterdam

Prescott, J. R. \& Hutton, J. T. (1994): Cosmic ray contributions to dose rates for luminescence and ESR dating: large depths and long-term time variations. - Radiat. Meas., 23: 497-500, Oxford.

Prescott, J. R. \& Stephan, L. G. (1982): The contribution of cosmic radiation to the environmental dose for thermoluminescent dating - Latitude, altitude and depth dependences. - PACT, 6: 17-25; Strasbourg.
ReEs-Jones, J. (1995): Optical dating of young sediments using fine-grain quartz. - Anc. TL, 13: 9-14, Aberystwyth.

Reimer, P. J., Baillie, M. G. L., Bard, E., Bayliss, A., Beck, W. J., Bertrand, C. J. H., Blackwell, P. G., Buck, C. E., Burr, G. S., Cutler, K. B., Damon, P. E., Edwards, R. L., Fairbanks, R. G., Friedrich, M., Guilderson, T. P., Hogg, A. G., Hughen, K. A., Kromer, B., McCormac, G., Manning, S., Bronk Ramsey, C., Reimer, R. W., Remmele, S., Southon, J. R., Stuiver, M., Talamo, S., Taylor, F. W. van der Plicht, J. \& Weyhenmeyer, C. E. (2004): Intcal04 terrestrial radiocarbon age calibration, 0-26 cal kyr BP. - Radiocarbon, 46: 10291058; Tuscon.

Richter, P. B. (2002): Das neolithische Erdwerk von Walmstorf, Ldkr. Uelzen: Studien zur Besiedlungsgeschichte der Trichterbecherkultur im südlichen Ilmenautal. - Veröff. d. Urgesch. Samml. Landesmus. Hannover, 49: 90 S.; Oldenburg (Isensee).

RoBerTs, H. M. (2008): The development and application of luminescence dating to loess deposits: a perspective on the past, present and future. - Boreas, 37: 483-507.

Roeschmann, G. (1957): Die Bodenbildung auf dem Flottsand im Bereich des Großblattes Bremen 1:100 000. 53 p.; Hannover (Amt für Bodenforschung).

SchiRnig, H. (1979): Die Siedlung auf dem schwarzen Berg bei Wittenwater, Kreis Uelzen. H. Schirnig (Ed.), Großsteingräber in Niedersachsen. - Veröff. d. Urgeschich. Samml. Landesmus. Hannover, 24: 244-246; Oldenburg (Isensee).

SchwANTes, G. (1952): Die Seedorf-Stufe. - In: Kivikoski, E. (Hrsg..): Corolla archaeologica in honorem C.A. Nordman. 68-76 S., Helsinki.

Spooner, N. A. (1994): The anomalous fading of infrared-stimulated luminescence from feldspars. - Radiat. Meas., 23: 625-632; Oxford.

Sprocкноғғ, E. (1975): Atlas der Megalithgräber Deutschlands 3. Niedersachsen - Westfalen. Textband. Bonn (Habelt).

Stuiver, M. \& Reimer, P. J. (1993): Extended 14C data base and revised Calib 3.0 14C age calibration program. - Radiocarbon, 35: 215-230; Tuscon.

VAN GeEL, B. (1978): A palaeoecological study of Holocene peat bog sections in Germany and the Netherlands. - Rev. Palaeobot. Palynol., 25: 1-120; Amsterdam.

van GeEL, B. (2001): Non-pollen palynomorphs. In: SMOL, J.P., BirKs, H.J.B. \& LAST, W.M. (Hrsg.): Tracking Environmental Change Using Lake Sediments, Volume 3: Terrestrial, Algal, and Siliceous Indicators. 99-119 S.; Dordrecht (Kluwer Academic Publishers).

van ReeuwiJK, L.P. (Ed.), (1992): Procedures for Soil Analysis. Wageningen (ISRIC).

VISOCEKAS, R. (2002): Tunnelling in afterglow, its coexistence and interweaving with thermally stimulated luminescence. - Radiat. Prot. Dosim., 100: 45-54; Oxford.

Visocekas, R., Spooner, N. A., Zink, A. \& Blanc, P. (1994): Tunnel afterglow, fading and infrared emission in thermoluminescence of feldspars. - Radiat. Meas., 23: 377-385; Oxford.

Wallinga, J., Bos, A. J. J., Dorenbos, P., Murray, A. S. \& Schokker, J. (2007): A test case for anomalous fading correction in IRSL dating. Quat. Geochronol., 2: 216-221; Amsterdam.

WintLE, A. G. (1973): Anomalous fading of thermoluminescence in mineral samples. - Nature, 245: 143-144; London.

ZolitschKa, B., BeHRe, K.-E., SCHNeIDER, J. (2003): Human and climatic impact on the environment as derived from colluvial, fluvial and lacustrine archives - examples from the Bronze Age to the Migration period, Germany. - Quat. Sci. Rev., 22: 81-100. 